\title{
Comparative study of the inflorescence, spikelet and flower development in species of Cynodonteae (Chloridoideae, Poaceae)
}

\author{
VANESA PILATTI ${ }^{1,2,5, *}$, SEBASTIÁN E. MUCHUT',2, NORA G. UBERTI-MANASSERO ${ }^{3,4}$, \\ ABELARDO C. VEGETTI ${ }^{1,3}$ and RENATA REINHEIMER ${ }^{3,4, *}$ \\ ${ }^{1}$ Morfología Vegetal, Facultad de Ciencias Agrarias, Universidad Nacional del Litoral, Santa Fe, \\ Argentina \\ ${ }^{2}$ Fellow of Consejo Nacional de Investigaciones Científicas y Técnicas de la República Argentina \\ (CONICET) \\ ${ }^{3}$ Member of Consejo Nacional de Investigaciones Científicas y Técnicas de la República Argentina \\ (CONICET) \\ ${ }^{4}$ Instituto de Agrobiotecnología del Litoral, Universidad Nacional del Litoral, CONICET, FBCB, Santa \\ Fe, Argentina \\ ${ }^{5}$ Current Address: Instituto Nacional de Tecnología Agropecuaria (INTA), Estación Experimental \\ Agropecuaria Rafaela, Ruta 34 km 227, CP 2300, Santa Fe, Argentina
}

Received 11 May 2018; revised 23 December 2018; accepted for publication 28 December 2018

\begin{abstract}
Inflorescence morphology in Poaceae subtribes Hilariinae, Monanthochloinae, Boutelouinae, Scleropogoninae and Muhlenbergiinae (Cynodonteae, Chloridoideae) has been revisited recently, but inflorescence development remains largely unexplored. The aim of this study is to contribute additional information on the development of inflorescences in Cynodonteae by generating data on Distichlis, Bouteloua, Munroa, Erioneuron and Muhlenbergia and to compare them with results for other grasses. Using scanning electron microscopy images, we identified common developmental patterns among grasses and described developmental novelties for Bouteloua, Distichlis and Muhlenbergia. Novel developmental features are: the amphipetal initiation of second-order branches along the inflorescence of $B$. curtipendula, the elongation of the internodes of the inflorescence branches before floral development in $M$. asperifolius and 'Type II' unisexual flowers in $D$. acerosa. Variable traits among studied species are: inflorescence symmetry, direction of branch and spikelet initiation and differentiation, number of developing stamens, glume developmental patterns and timing of the arrest of gynoecium development during the formation of unisexual flowers. Our results allow us to postulate that a delicate balance of phytohormones may direct early development of grass inflorescence branching system by controlling direction of first-order branch differentiation. The approach used here provides a link between definitive structures and the underlying genetics.
\end{abstract}

ADDITIONAL KEYWORDS: branching - common patterns - developmental novelties - floret - grasses - spikelet.

\section{INTRODUCTION}

Tribe Cynodonteae are a diverse group of grasses made up by 839 species grouped into 96 genera and 21 subtribes, mainly distributed in Africa, Asia, Australia and America (Soreng et al., 2015; Peterson, Romaschenko \& Herrera Arrieta, 2016). In

*Corresponding authors. E-mail: vanesapilatti@hotmail.com, rreinheimer@ial.santafe-conicet.gov.ar the tribe, subtribes Hilariinae, Monanthochloinae, Boutelouinae, Scleropogoninae and Muhlenbergiinae form a monophyletic clade with most of their species growing in the Western Hemisphere (Peterson, Romaschenko \& Herrera Arrieta, 2015; Soreng et al., 2015; Peterson et al., 2016). The species that make up this lineage show wide variation in their reproductive structures. One major characteristic feature is the great diversity of spikelets and inflorescences found between and in these subtribes. In particular, spikelets 
may be single- or many-flowered and they may enclose unisexual, bisexual or both types of flowers (Anton, Anton \& Hunziker, 1978; Hunziker \& Anton, 1979; Clayton \& Renvoize, 1986; Nicora \& Rúgolo de Agrasar, 1987; Watson \& Dallwitz, 1992; Peterson, Webster \& Valdés-Reyna, 1997; Anton, Connor \& Astegiano, 1998; Negritto et al., 2003; Herrera Arrieta, Peterson \& De la Cerda Lemus, 2004; Peterson, Valdés-Reyna \& Herrera Arrieta, 2007). The inflorescences of this lineage may be panicles (composed of a main axis bearing ramified lateral branches) or racemes (in which the main axis develops non-ramified first-order branches) of spikelets. Recent studies using a comparative approach classified the inflorescences of the clade into five groups based of the branching patterns and the presence/ absent of terminal spikelet (Pilatti \& Vegetti, 2014; Pilatti, 2016; Pilatti et al., 2017): panicle of spikelets with a terminal spikelet and non-homogenized firstorder branches (unevenly branched, Rúa \& Weberling, 1998) (Fig. 1A); panicle of spikelets with a terminal spikelet and homogenized first-order branches (evenly branched, Rúa \& Weberling, 1998) (Fig. 1B); panicle of spikelets without a terminal spikelet, with homogenized first-order branches (Fig. 1C); panicle of spiciform first-order branches without a terminal spikelet with homogenized first-order branches (Fig. 1D) and racemes of spikelets with a terminal spikelet and homogenized first-order branches (Fig. 1E).

Comparative studies on inflorescence development shed light on various ontogenetic patterns that determine the formation of definitive structures and add comprehensive knowledge of the morphology of reproductive structures (Kellogg, 2007). There are now many studies of the development of reproductive structures in Poaceae (e.g. Stür, 1986; Frank, 1998; Le Roux \& Kellogg, 1999; Orr et al., 2002; Doust \& Kellogg, 2002; Kellogg, Hiser \& Doust, 2004; Bess, Doust \& Kellogg, 2005; Reinheimer, Pozner \& Vegetti, 2005a; Liu et al., 2007; Sajo, Lonhi-Wagner \& Rudall, 2007; Kinney, Columbus \& Friar, 2008; Reinheimer et al., 2009, 2010;

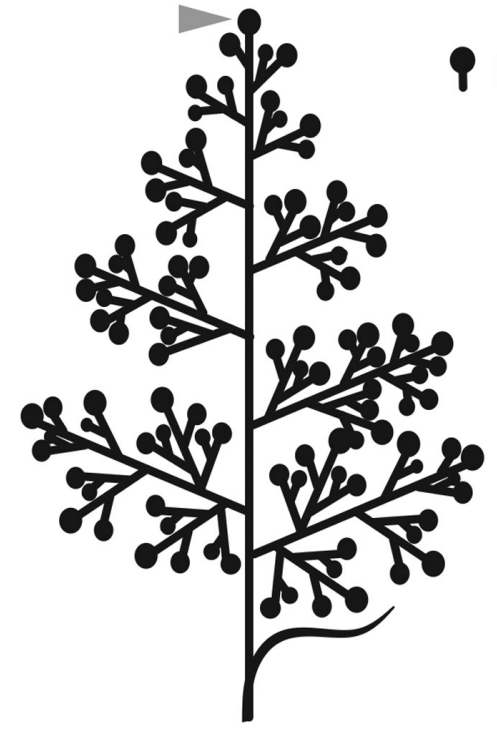

A

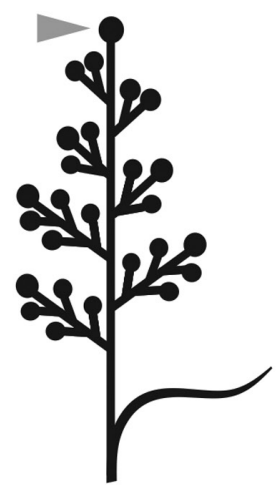

B
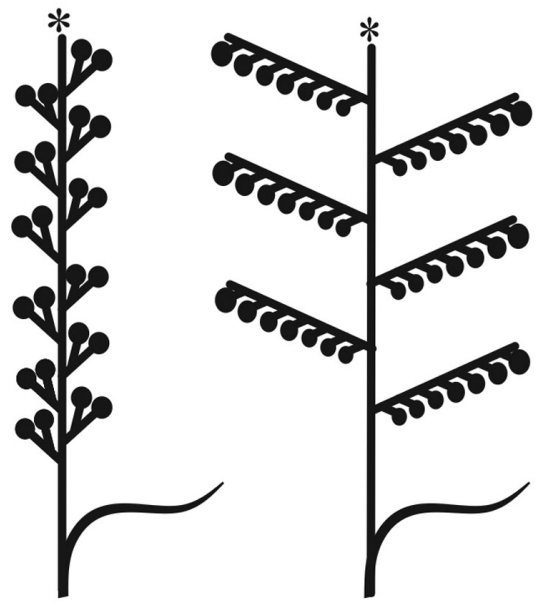

$\mathrm{D}$

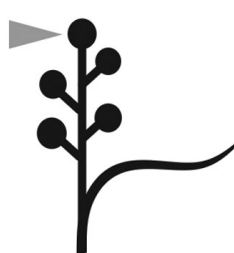

$\mathrm{E}$

Figure 1. A-E, Simplified diagrams of the different inflorescence types found in the studied group as described in Pilatti \& Vegetti (2014), Pilatti (2016) and Pilatti et al. (2017). A, Panicle of spikelets with terminal spikelet (at arrowhead) and nonhomogenized first-order branches. B, Panicle of spikelets with terminal spikelet (at arrowhead) and homogenized first-order branches. C, Panicle of spikelets without terminal spikelet and homogenized first-order branches. D, Panicle of spiciform first-order branches without terminal spikelet and homogenized first-order branches. E, Raceme of spikelets with terminal spikelet (at arrowhead) and homogenized first-order branches. References and abbreviations for all figures: $a=$ anther; $a m=$ apical meristem; $b^{1}=$ first-order branch; $b^{2}=$ branch of second order; $b^{3}=$ branch of third order; $b r=$ bract; $c=$ carpel; $c o=$ anther connective; $d f m=$ meristem of distal flower; $f i=$ filament; $f m=$ floral meristem; $g=$ gynoecium; $l=$ lemma; $l^{1}=$ lemma of proximal flower; $l^{2}=$ lemma of distal flower; $l g l=$ lower glume; $l o=$ lodicule; $o v=$ ovary; $p a=$ inflorescence main axis; $p a l=$ palea $; f m=$ meristem of proximal flower; $r a=$ spikelet rachilla; $s p=$ spikelet; $s t a=$ stamen; stam = staminod; stig = stigma; sty $=$ style; $t=$ theca ts = terminal spikelet; $t s b^{1}=$ terminal spikelet of first-order branch; $u g l=$ upper glume; $v l=$ vegetative leaf. The asterisks represent the aborted main axis. The stars indicate absence of terminal spikelet. Bars $=100 \mu \mathrm{m}$. 
Sajo et al., 2012; Kellogg et al., 2013), but information relating to the development of the reproductive systems in grasses is fragmentary, focusing on some species in particular, and a thorough comparative analysis has not yet been carried out. The aim of this work is to provide additional information on the development of Cynodonteae inflorescences by: (1) understanding the development patterns involved in the formation of all five types of inflorescences in the studied group; (2) identifying changes in the development that may account for the diversity of inflorescences in the group; (3) describing and comparing development patterns of spikelets and flowers and (4) recognizing similarities with and/or differences from the development patterns identified in other grasses.

\section{MATERIAL AND METHODS}

We investigated the development of inflorescences, spikelets and flowers of representatives of Distichlis Raf., Bouteloua Lag., Munroa Torr., Erioneuron Nash and Muhlenbergia Schreb. (Table 1). Hilaria Kunth, Blepharidachne Hack., Swallenia Soderstr. \& H.F.Decker and Scleropogon Phil were not included because of unavailability of material. The plants used were collected in the field and grown in a greenhouse at the Agronomy School of the Universidad del Litoral (Argentina).
Samples of inflorescences, spikelets and flowers at different stages of development were fixed in FAA solution (formalin: acetic acid: 70\% ethanol, 10:5:85, $\mathrm{v} / \mathrm{v})$ for $24 \mathrm{~h}$ and then transferred to $70 \%$ ethanol. For scanning electron microscope (SEM) observation, the reproductive structures were dissected and classified using a stereoscopic microscope (Nikon SMZ-10) according to the stage of development. The samples were dehydrated through ethanol plus two final changes of $100 \%$ acetone. The dehydrated material was critical point dried using $\mathrm{CO}_{2}$ as a transition fluid and coated with gold palladium using a Sputter Coater Emitech SC7640 equipment. All samples were observed and photographed using a FEI QUANTA 200 SEM at the Microscopy Service of the Institute of Physics (CONICET-UNR-Rosario, Argentina).

\section{RESULTS}

\section{DEVELOPMENT OF THE BRANCHING SYSTEM OF INFLORESCENCES}

During the vegetative growth stage of all the studied species, the shoot apical meristem was observed to produce leaf primordia in two ranks, that is, in a distichous arrangement (Fig. 2A). The moment of transition from the vegetative state to the flowering

Table 1. Voucher information for the studied taxa

\begin{tabular}{|c|c|c|}
\hline Species & Collection State & Voucher \\
\hline Distichlis acerosa (Griseb.) H.L.Bell \& Columbus & $\begin{array}{l}\text { Córdoba, La Rioja, Catamarca } \\
\text { (Argentina) }\end{array}$ & $\begin{array}{l}\text { Pilatti, V. y col., 30, 34, 35, } \\
147 \text { (SF) }\end{array}$ \\
\hline Distichlis humilis Phil. & Salta (Argentina) & Pilatti, V. y col., 91, 100 (SF) \\
\hline Distichlis spicata (L.) Greene & Santa Fe (Argentina) & Vegetti, A.C. 1290 (SF) \\
\hline Bouteloua aristidoides (Kunth) Griseb. & Córdoba (Argentina) & Pilatti, V. y col., 26 (SF) \\
\hline Bouteloua barbata Lag. & Jujuy (Argentina) & Pilatti, V. y col., 72 (SF) \\
\hline Bouteloua curtipendula (Michx.) Torr. & Córdoba (Argentina) & Pilatti, V. y col., 7 (SF) \\
\hline Bouteloua megapotamica (Spreng.) Kuntze & Córdoba, Santa Fe (Argentina) & $\begin{array}{l}\text { Pilatti, V. y col., 13, 89, } 160 \\
\text { (SF) }\end{array}$ \\
\hline Bouteloua simplex Lag. & Jujuy (Argentina) & Pilatti, V. y col., 64, 82 (SF) \\
\hline Erioneuron avenaceum (Kunth) Tateoka & Jujuy (Argentina) & Pilatti, V. y col., 73, 84 (SF) \\
\hline $\begin{array}{l}\text { Muhlenbergia asperifolia (Nees \& Meyen ex } \\
\text { Trin.) Parodi }\end{array}$ & Jujuy (Argentina) & Pilatti, V. y col., 58 (SF) \\
\hline Muhlenbergia bryophilus (Döll) P.M.Peterson & Tucuman (Argentina) & Pilatti, V. y col., 143 (SF) \\
\hline Muhlenbergia peruviana (P.Beauv.) Steud. & Tucuman (Argentina) & Pilatti, V. y col., 139 (SF) \\
\hline Muhlenbergia phalaroides (Kunth) P.M.Peterson & Jujuy (Argentina) & Pilatti, V. y col., 85 (SF) \\
\hline Muhlenbergia tenuifolia (Kunth) Kunth & Salta (Argentina) & Pilatti, V. y col., 112 (SF) \\
\hline Munroa argentina Griseb. & Jujuy (Argentina) & Pilatti, V. y col., 74 (SF) \\
\hline Munroa decumbens Phil. & Salta (Argentina) & Pilatti, V. y col., 93 (SF) \\
\hline Munroa mendocina Phil. & La Rioja (Argentina) & Pilatti, V. y col., 36 (SF) \\
\hline
\end{tabular}

Abbreviations: SF, Herbario ‘Arturo Ragonese' de la Universidad Nacional del Litoral. 
state becomes evident when the apical meristem lengthens over the latest leaf primordium to start forming the main axis of the inflorescence (Fig. 2B).

Following the transition to flowering, the main axis of the inflorescence continues developing by increase in length; the first-order branches initiate in an acropetal direction (Table 2; Fig. 3A, B). Once first-order branches have been initiated, the apical meristem of the main axis develops a terminal spikelet (Fig. 3C). However, in species of Bouteloua, D. acerosa (Griseb.) H.L.Bell \& Columbus and M. bryophilus (Döll) P.M.Peterson, the apical meristem arrests its activity before the terminal spikelet is initiated (Fig. 3D-I).

First-order branches become arranged differently on the main axis depending on their point of initiation. Based on this, three different types of symmetry have been identified: (1) spiral; (2) strictly distichous and (3) dorsiventral distichous (Table 2). An inflorescence has a spiral symmetry when the first-order branch primordia initiate one by one in more than two ranks on the main axis (Fig. 3C). Inflorescences are distichous when first-order branches initiate in two opposite ranks separated from each other by and angle of $180^{\circ}$. In such cases, the main axis may be round or oval, and front and back sides lack ramifications (Fig. 3E, F). In the dorsiventral distichous inflorescence, first-order branches are initiated in two ranks and develop towards one side of the main axis; this inflorescence type has distinct front and back sides. In such cases, the main axis is triquetrous, and the back side lacks ramifications (Fig. 3H, I). Disticlis acerosa, B. simplex Lag., M. argentina Griseb., $M$. decumbens Phil. and $M$. mendocina Phil. have been excluded from the classification due to the fact that they bear inflorescences with a single first-order branch.

The differentiation of a first-order branch consists of its lengthening or flattening, which is associated with the initiation of second-order branches. In the studied species, it was observed that first-order branches initiate secondary branches in three directions along the inflorescence axis (Table 2): (1) acropetal (Fig. 3C); (2) amphipetal (Fig. 3E) or (3) basipetal (Fig. 3H). Additionally, second-order branches are initiated on the first-order branches in an acropetal direction (Fig. 3C, E, H).

The differentiation of a second-order branch is morphologically determined by the initiation of third-order branches or the initiation of a terminal spikelet. Based on these criteria, second-order branches may differentiate in an acropetal (Fig. 4A) or a basipetal (Fig. 4B) direction (Table 2). Thirdorder branches are initiated in the inflorescence and on the first-order branches in an acropetal direction (Fig. 4A).
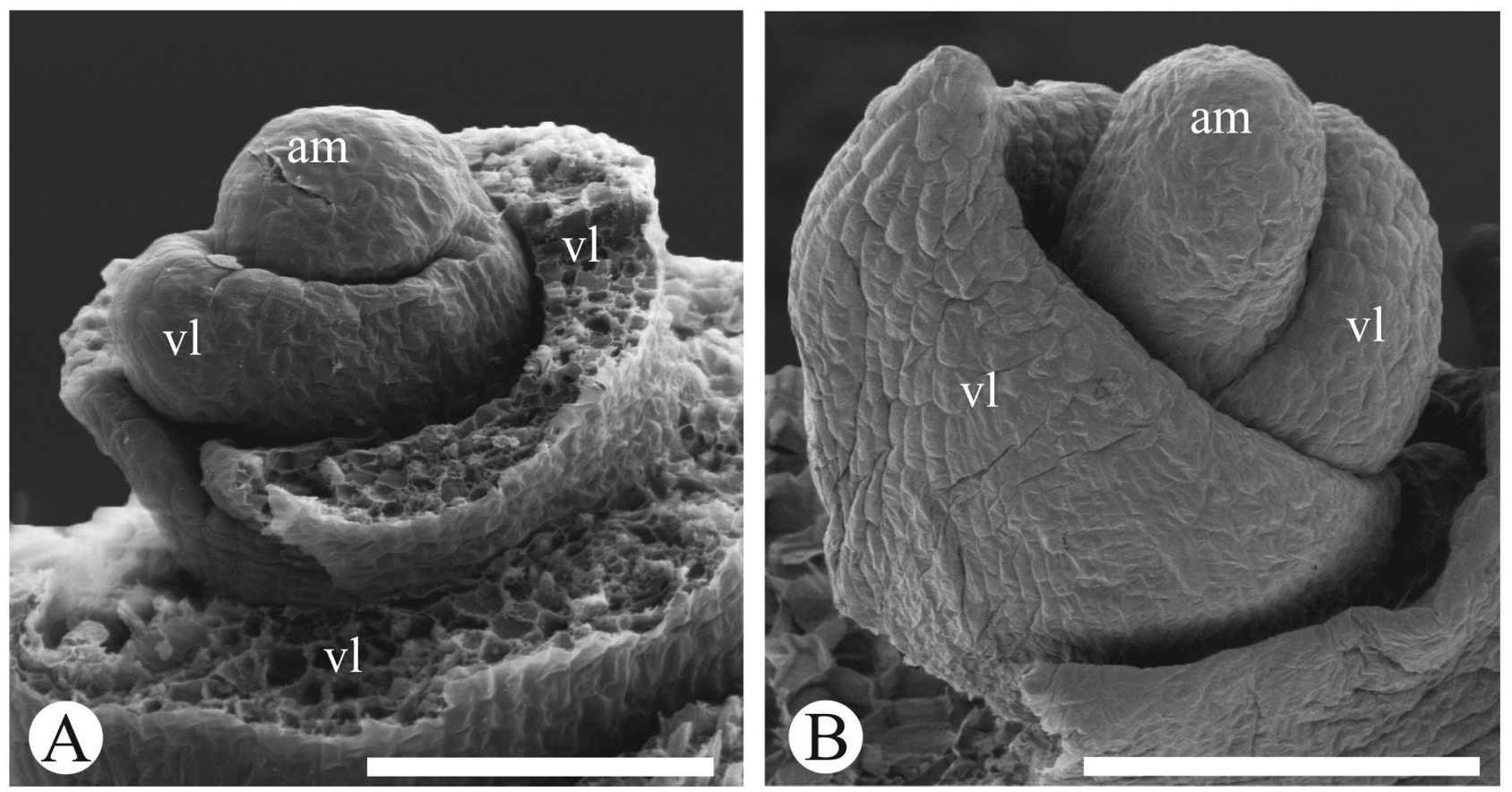

Figure 2. Vegetative stage in Distichlis acerosa and transition to flowering in Munroa argentina (scanning electron micrographs). A, Apical meristem producing vegetative leaves during the vegetative stage. B, Elongation of the apical meristem above the last developed leaf during transition to flowering. 
Table 2. Differences observed during the development of the inflorescence branch system of studied taxa

\begin{tabular}{|c|c|c|c|c|c|c|}
\hline Species & i symmetry & $\begin{array}{l}\text { Direction of } \\
\mathrm{b}^{1} \text { initiation } \\
\text { along the } \mathrm{i}\end{array}$ & $\begin{array}{l}\text { Direction of } b^{1} \\
\text { differentiation } \\
\text { along the } \mathrm{i}\end{array}$ & $\begin{array}{l}\text { Direction of } \\
\mathrm{b}^{2} \text { initiation } \\
\text { along the } \mathrm{i}\end{array}$ & $\begin{array}{l}\text { Direction of } \\
\mathrm{b}^{2} \text { initiation } \\
\text { on the } \mathrm{b}^{1}\end{array}$ & $\begin{array}{l}\text { Direction of } b^{2} \\
\text { differentiation } \\
\text { on the } b^{1}\end{array}$ \\
\hline $\begin{array}{l}\text { Bouteloua } \\
\text { aristidoides }\end{array}$ & Dorsiventral & Acropetal & Basipetal & Basipetal & Acropetal & Basipetal \\
\hline Bouteloua barbata & Distichous & Acropetal & Basipetal & Basipetal & Acropetal & Basipetal \\
\hline $\begin{array}{l}\text { Bouteloua } \\
\text { curtipendula }\end{array}$ & Distichous & Acropetal & Amphipetal & Amphipetal & Acropetal & Basipetal \\
\hline $\begin{array}{l}\text { Bouteloua } \\
\text { megapotamica }\end{array}$ & Distichous & $?$ & Basipetal & $?$ & $?$ & Basipetal \\
\hline Bouteloua simplex & - & - & - & - & Acropetal & Basipetal \\
\hline $\begin{array}{l}\text { Muhlenbergia } \\
\text { asperifolia }\end{array}$ & Spiral & $?$ & $?$ & $?$ & $?$ & $?$ \\
\hline $\begin{array}{l}\text { Muhlenbergia } \\
\text { bryophilus }\end{array}$ & Dorsiventral & Acropetal & Basipetal & Basipetal & Acropetal & Basipetal \\
\hline $\begin{array}{l}\text { Muhlenbergia } \\
\text { peruviana }\end{array}$ & Dorsiventral & Acropetal & Acropetal & Acropetal & Acropetal & Acropetal \\
\hline $\begin{array}{l}\text { Muhlenbergia } \\
\text { phalaroides }\end{array}$ & Spiral & Acropetal & Basipetal & $?$ & $?$ & $?$ \\
\hline $\begin{array}{l}\text { Muhlenbergia } \\
\text { tenuifolia }\end{array}$ & Spiral & Acropetal & Acropetal & Acropetal & Acropetal & Acropetal \\
\hline
\end{tabular}

Abbreviations: $b^{1}$, branch of first order; $b^{2}$, branches of second order; i, inflorescence; (-) non-applicable; (?) missing data.

\section{ELONGATION OF THE INTERNODES}

We observed variations in terms of types of internodes that elongate and in the stage during which lengthening takes place. The main axis of the inflorescence comprises: (1) a basal internode, from the node of flag leaf insertion to the node of insertion of the most proximal first-order branch and (2) the internodes that develop between first-order branches. In most of the studied species, inflorescences emerge from the flag leaf through the elongation of the basal internode of the main axis (Fig. 5A). Sometimes, the basal internode of the main axis never elongates, and the inflorescence remains partially included within the vegetative leaves, as the case of Munroa and D. acerosa (Fig. 5B).

The internodes of the main axis usually elongate, with the exception of Munroa spp. (Fig. 6A). Lengthening of the internodes, when it occurs, may be proportional or differential. When the former occurs, all internodes will be of similar length at maturity (Fig. 6B). In the latter case, internodes will vary in length and some first-order branches will remain close to one another, thus appearing as whorled, as in the inflorescence of M. asperifolius (Nees \& Meyen ex Trin.) Parodi (Fig. 6C).

The internodes of the first-order branches usually elongate proportionally (Fig. 6D), but in M. asperifolius (Fig. 6C) these internodes lengthen differentially. In most of the studied species, the pedicel that subtends the spikelet was observed to be shorter than the length of the developing spikelet (Fig. 6A, B, D, E), but in M. asperifolius the pedicel is longer (Fig. 6C, F).

In terms of timing of internode elongation, the main axis internodes increase in length at a late stage, when spikelets and flowers have fully developed their organs (Fig. 6E). The elongation of the internodes of the first-order branches and pedicels takes place when the floral organs have already differentiated (Fig. $6 \mathrm{E})$. However, in $M$. asperifolius, the elongation of the branch internodes occurs before the floral organs initiate (Fig. 6F).

\section{DEVELOPMENT OF THE SPIKELETS}

Spikelets begin to form with a change in the apical end of the branches and/or the main axis, which generally relates to the initiation of two primordia of alternate, concave glumes. Table 3 outlines the main differences found during the development of spikelets.

The spikelet begins developing with the initiation of the lower glume, followed by the upper glume (Fig. 4A, B), except in D. acerosa, in which glumes are never initiated (Fig. 7A). Both glumes usually differentiate and are visible at maturity (Fig. 7B). However, in M. mendocina, glume primordia are initiated, but arrest their development at an early stage; therefore, they are not visible in mature spikelets (Fig. 7C).

The apical meristem of the inflorescence main axis may end with the development of a terminal 

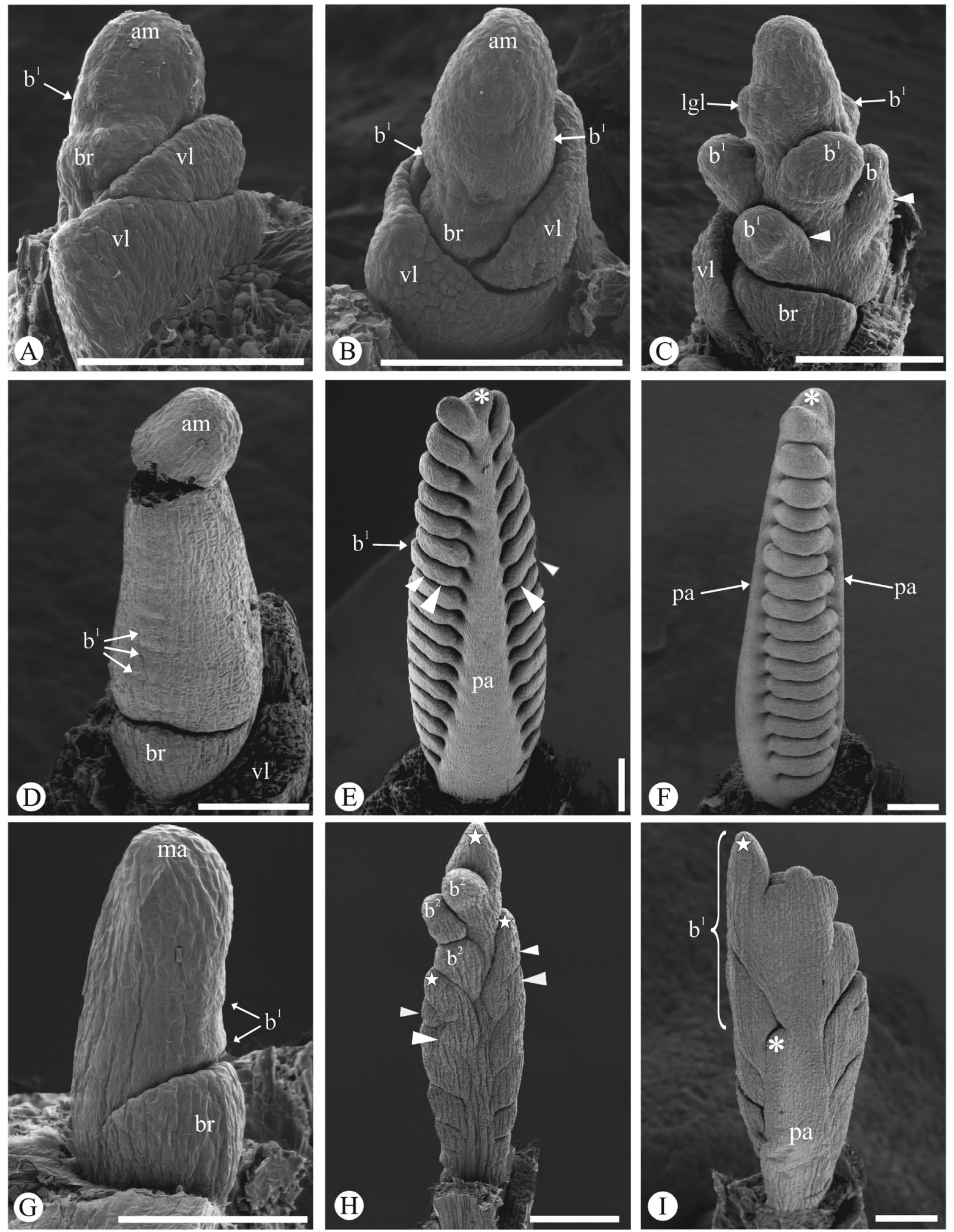

Figure 3. Patterns of main axis and first-order branches development (scanning electron micrographs). A-C, Three successive developmental stages of Muhlenbergia tenuifolia inflorescence, with acropetal initiation of first-order branches, terminal spikelet at the tip of the main axis and spiral symmetry. A, Elongation of apical meristem above the last formed leaf during transition to flowering and initiation of first first-order branch. B, Initiation of new first-order branches from 

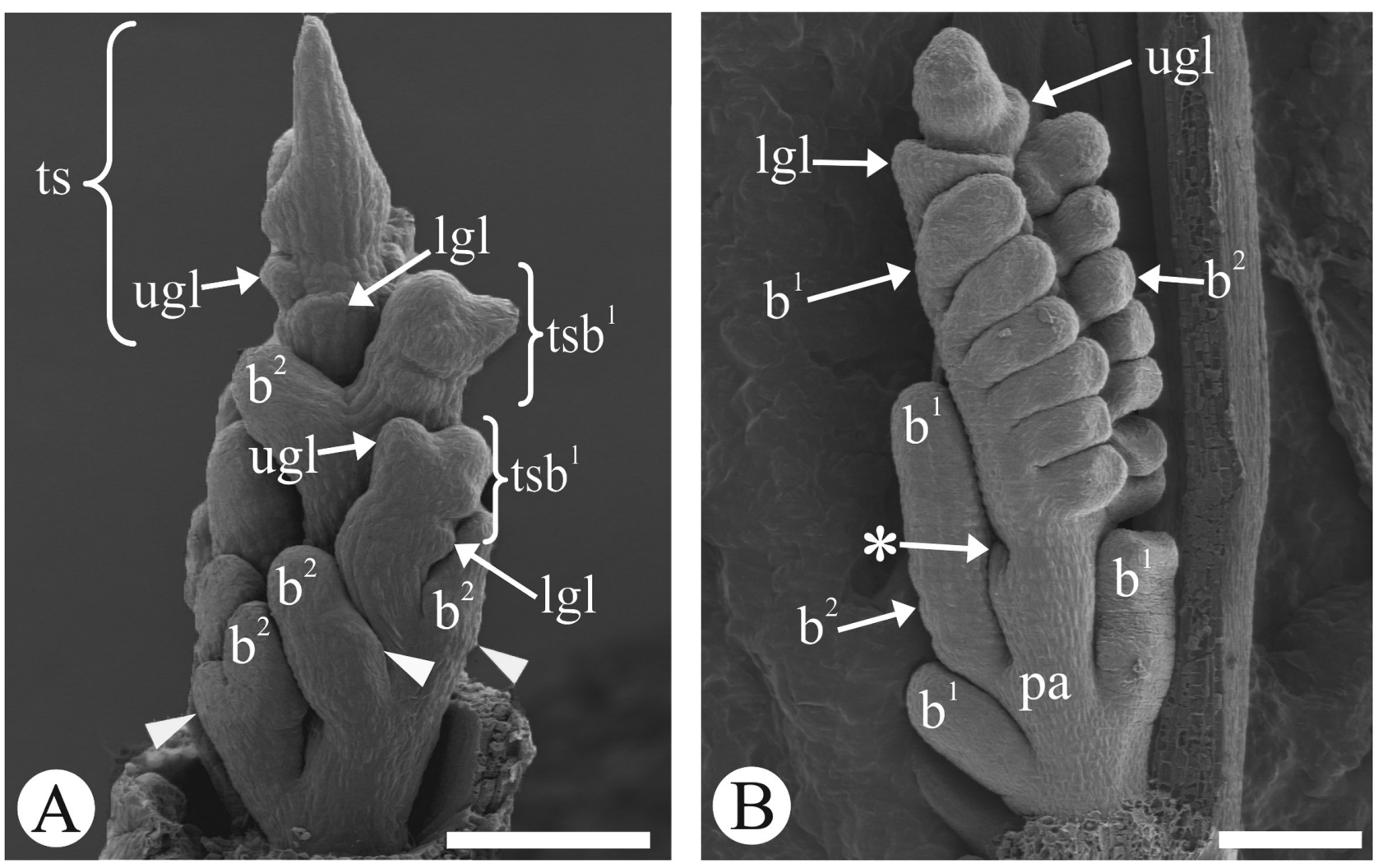

Figure 4. Differentiation of second-order branches along first-order branches and inflorescence (scanning electron micrographs). A, Initiation of third-order branches (at white arrowhead) on second-order branches with acropetal direction along the first-order branches and along the inflorescence of Muhlenbergia peruviana. B, Spikelet initiation on second-order branches with basipetal direction along the first-order branches and along the inflorescence of Bouteloua barbata.

spikelet. In such cases, the terminal spikelet is the first spikelet on the entire inflorescence in which the glume primordia are initiated (Figs 3C, 4A, 6A, 6F). Alternatively, the apical meristem of the main axis may end before developing the terminal spikelet, as observed in D. acerosa, M. bryophilus and Bouteloua sp. In such cases, the apical meristem may either end in a sterile prolongation (Fig. $3 \mathrm{E}, \mathrm{F}$ ) or be laterally displaced by the most distal first-order branch that takes on the position of the main axis (Figs 3I, 4B, 6B, D, 7A, B).

As in the main axis, the apical meristem of the first-order branches may end with the development of a terminal spikelet (Figs 4A, 6A, C, E, F, 7A, B). Sometimes, first-order branches end their development before developing a terminal spikelet, as

apical meristem in acropetal direction. C, Differentiation of first-order branches, initiation of second-order branches (at white arrowhead) in acropetal direction on the inflorescence, initiation of terminal spikelet and spiral symmetry of the inflorescence. D-F, Three successive developmental stages of Bouteloua curtipendula inflorescence, with acropetal initiation of first-order branches, without terminal spikelet in the main axis and distichous symmetry. D, Elongation of apical meristem and initiation of first-order branches in acropetal direction. E, Beginning of differentiation of first-order branches located in the middle region of the inflorescence with initiation of second-order branches (at white arrowhead), sterile ending of main axis and distichous symmetry of inflorescence. F, Lateral view of inflorescence displaying the disposition of first-order branches separated by an angle of $180^{\circ}$. G-I, Three successive developmental stages of the inflorescence of Bouteloua aristidoides, with acropetal initiation of first-order branches in dorsiventral distichous disposition and without terminal spikelet at the tip of the main axis. G, Elongation of apical meristem, above scale leaf, initiated during transition to flowering and initiation of first first-order branches in acropetal direction. H, Front side of inflorescence where firstorder branches differentiate in basipetal direction; initiation of second-order branches in acropetal direction on first-order branches and basipetal direction along the inflorescence, differentiation of second-order branches in basipetal direction on first-order branches, absence of terminal spikelet in first-order branches. I, Back side of inflorescence main axis without branches. 

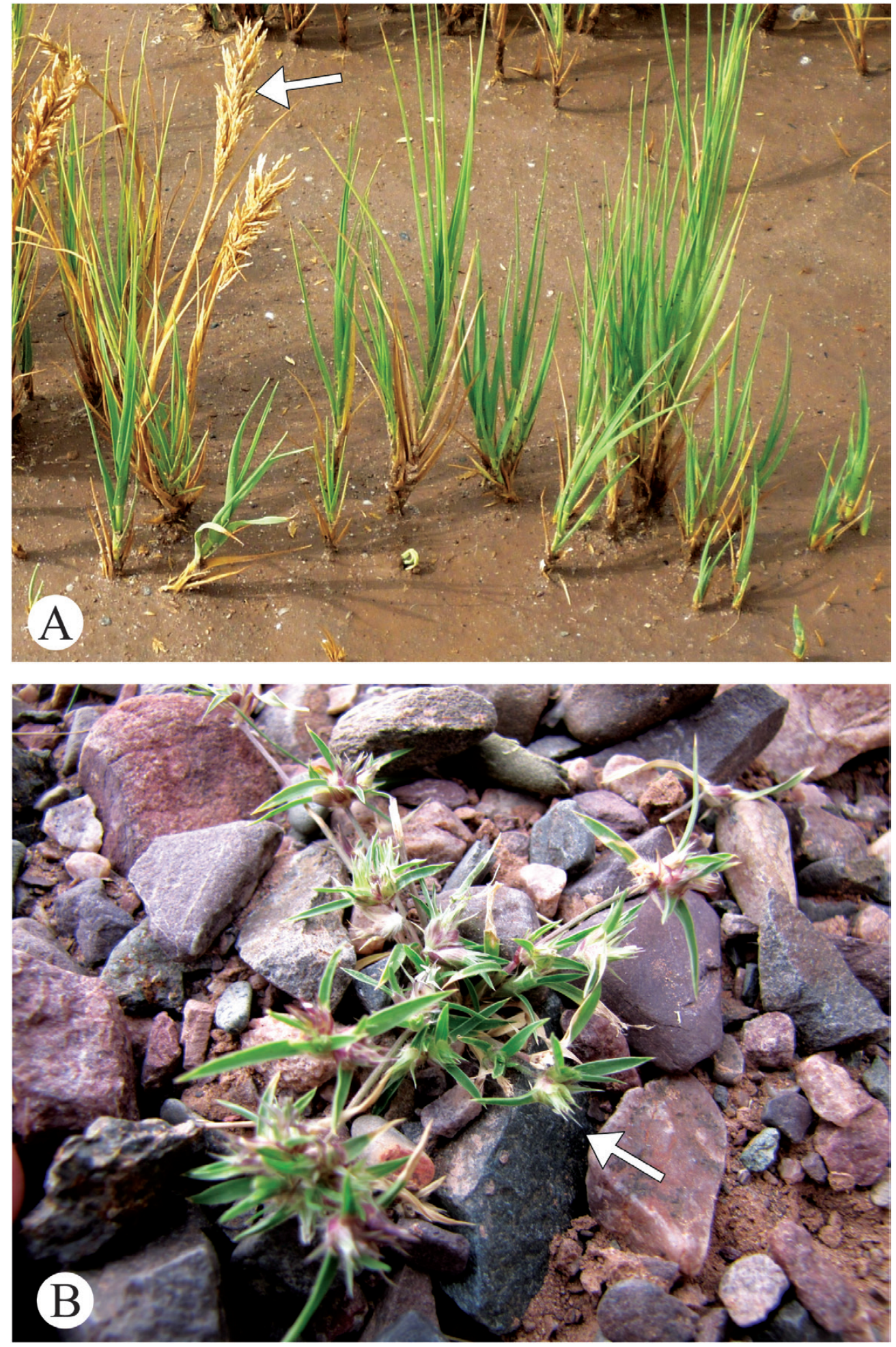

Figure 5. Photographs of mature inflorescences. A, Distichlis spicata with elongated basal internode of the inflorescence above scale leaf (exerted inflorescence at arrow). B, Non-elongated basal internode of Munroa argentina inflorescence which stays partially included (at arrow) within vegetative leaves. 

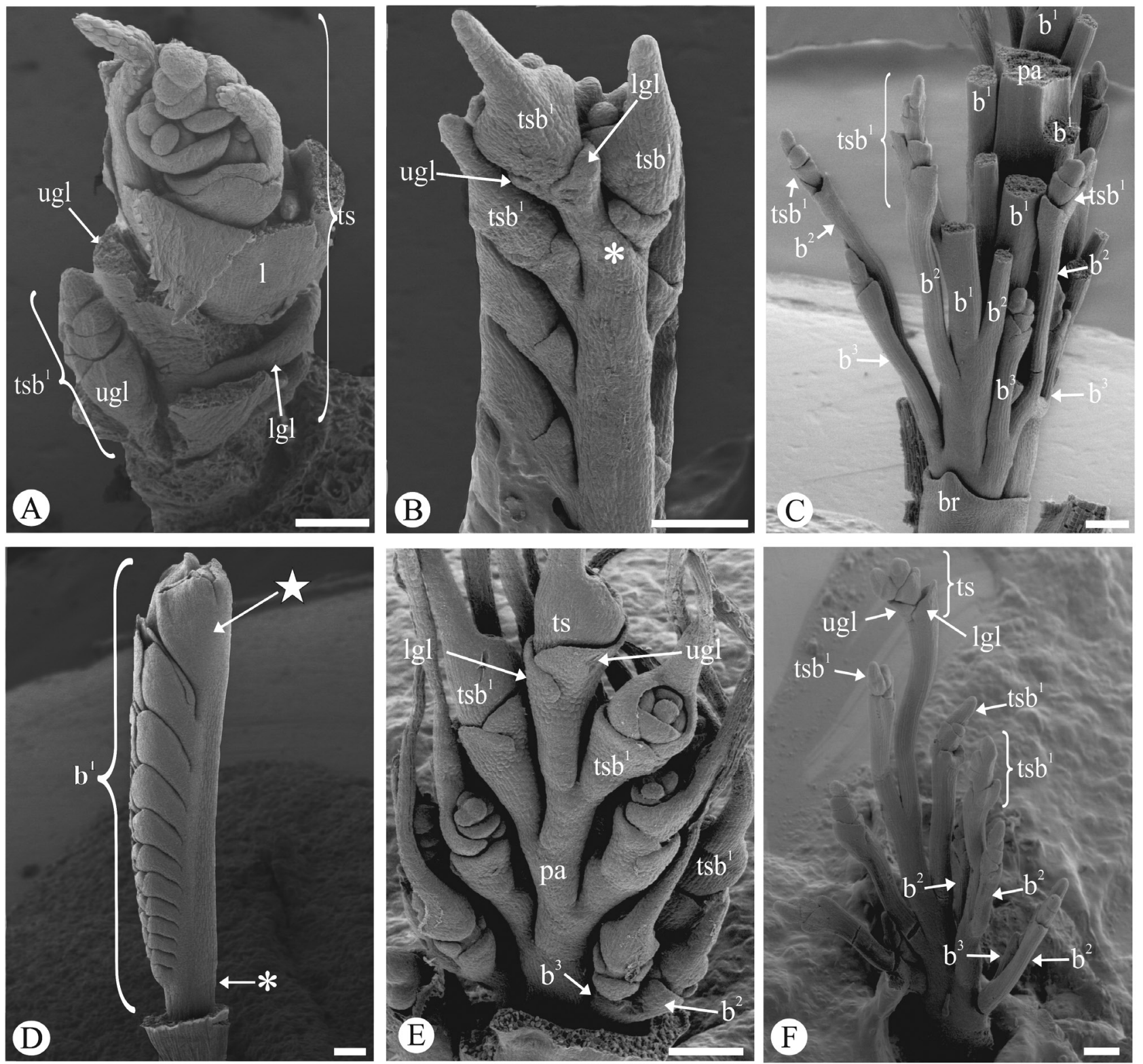

Figure 6. Patterns of internode development along inflorescences and first-order branches (scanning electron micrographs). A, Inflorescence of Munroa decumbens, where the main axis shows no elongation. B, Back side view of Muhlenbergia bryophilus inflorescence, displaying equally long internodes along the main axis. C, Inflorescence proximal region of Muhlenbergia asperifolius, displaying irregular internodes along the main axis and first-order branches. D, Lateral view of Bouteloua simplex inflorescence, displaying a primary branch in terminal position with its internodes proportionally separated from each other. E, Internode elongation along the main axis and first-order branches after floral organs formation in Muhlenbergia peruviana. F, Distal portion of an inflorescence of Muhlenbergia asperifolius, in which internode elongation in first-order branches take place before floral organ formation.

in Bouteloua spp. In such cases, the first-order branch may end with a sterile prolongation (Fig. $3 \mathrm{H}, \mathrm{I}$ ) or it may develop glumes that enclose the exhausted meristem (Figs 6D, 7B).

Three different sequences of spikelet initiation (here named arbitrarily sequences A, B and C) have been observed (Fig. 8). In sequence A, the terminal spikelet of the main axis initiates first followed by the terminal spikelets of the first-order branches, then the spikelets on the end of the second-order branches and, finally, the spikelets of the third-order branches (Fig. 8A). In sequence $\mathrm{B}$, the terminal spikelet of the first-order branch initiates first due to the lack of the terminal spikelet of the main axis followed by the 
Table 3. Differences observed during the spikelet development of the genus Distichlis, Bouteloua, Muhlenbergia and Munroa

\begin{tabular}{|c|c|c|c|c|c|c|}
\hline Species & $\begin{array}{l}\text { Glume } \\
\text { development }\end{array}$ & $\begin{array}{l}\text { ts } \\
\text { development }\end{array}$ & $\begin{array}{l}\mathrm{tsb}^{1} \\
\text { development }\end{array}$ & $\begin{array}{l}\text { Direction } \\
\text { of spikelet } \\
\text { initiation } \\
\text { along the } \mathrm{i}\end{array}$ & $\begin{array}{l}\text { Direction } \\
\text { of spikelet } \\
\text { initiation on the } \\
\mathrm{b}^{1} \text { along the } \mathrm{i}\end{array}$ & $\begin{array}{l}\text { Direction } \\
\text { of spikelet } \\
\text { initiation } \\
\text { on the } b^{2} \\
\text { along the } b^{1}\end{array}$ \\
\hline Distichlis acerosa & No & No & Yes & - & - & - \\
\hline Bouteloua aristidoides & Yes & No & No & Pattern C & Basipetal & Basipetal \\
\hline Bouteloua barbata & Yes & No & No & Pattern C & Basipetal & Basipetal \\
\hline Bouteloua curtipendula & Yes & No & No & Pattern C & Basipetal & Basipetal \\
\hline Bouteloua megapotamica & Yes & No & No & Pattern C & Basipetal & Basipetal \\
\hline Bouteloua simplex & Yes & No & No & Pattern C & - & Basipetal \\
\hline Muhlenbergia asperifolia & Yes & Yes & Yes & Pattern A & $?$ & Basipetal \\
\hline Muhlenbergia bryophilus & Yes & No & Yes & Pattern B & Basipetal & Basipetal \\
\hline Muhlenbergia peruviana & Yes & Yes & Yes & Pattern A & Basipetal & Basipetal \\
\hline Muhlenbergia phalaroides & Yes & Yes & Yes & $?$ & Basipetal & Basipetal \\
\hline Muhlenbergia tenuifolia & Yes & Yes & Yes & Pattern A & Basipetal & Basipetal \\
\hline Munroa argentina & Yes & Yes & Yes & Pattern A & - & - \\
\hline Munroa decumbens & Yes & Yes & Yes & Pattern A & - & - \\
\hline Munroa mendocina & Yes & Yes & Yes & Pattern A & - & - \\
\hline
\end{tabular}

Abbreviations: $b^{1}$, branch of first order; $b^{2}$, branch of second order; i, inflorescence; ts, terminal spikelet; tsb ${ }^{1}$, terminal spikelet of the first order branches. (-) non-applicable; (?) missing data.
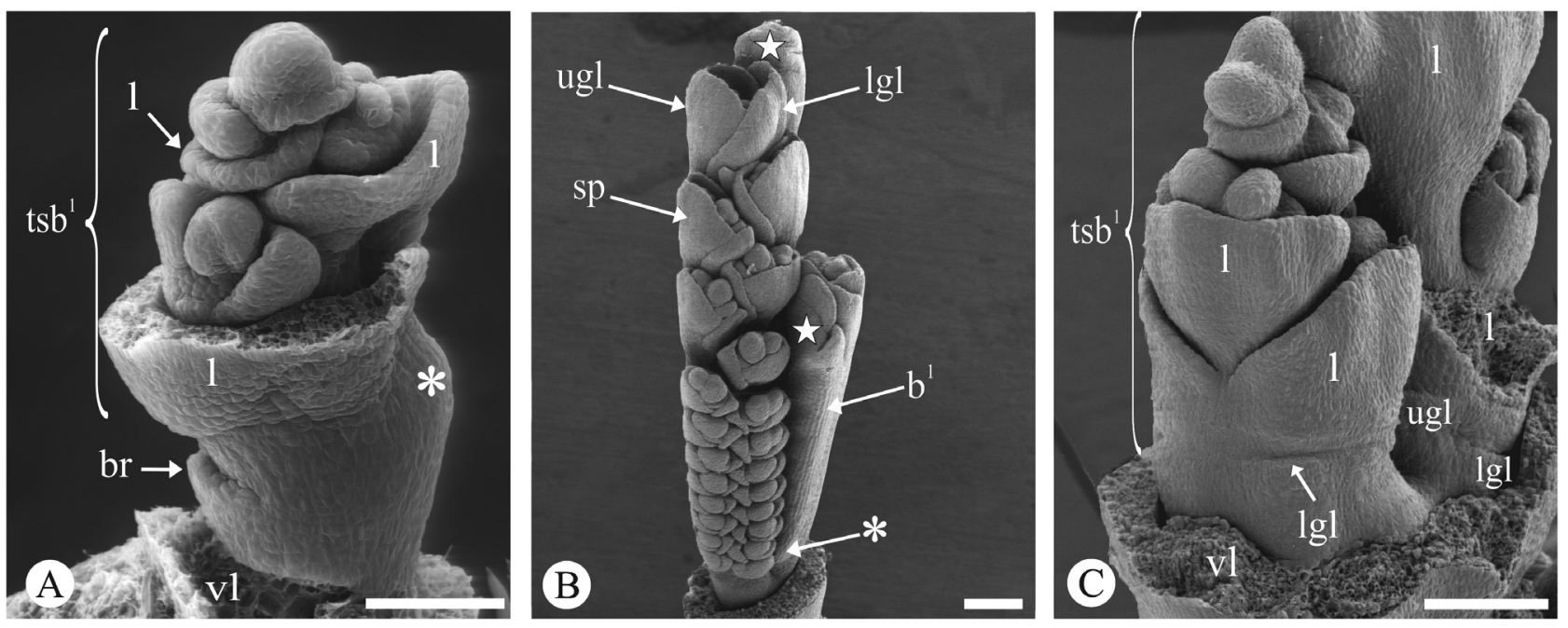

Figure 7. Glume initiation and differentiation (scanning electron micrographs). A, Absence of glumes initiation in Distichlis acerosa. B, Glume initiation and differentiation in Bouteloua barbata. C, Glume initiation and aborted development in Munroa mendocina.

spikelets on the end of the second-order branches (Fig. $8 B$ ). In sequence $\mathrm{C}$, the spikelet of the second-order branches initiates first due to the lack of the terminal spikelet both of the main axis and of the first-order branches (Fig. 8C). Initiation of spikelets on the end of the second-order branches begins in the last formed first-order branch of the inflorescence and proceeds basipetally along the inflorescences and over the firstorder branches (Figs 4A, 6E, F, 8).

Muhlenbergia peruviana (P.Beauv.) Steud., M. tenuifolia (Kunth) Kunth and M. asperifolius have inflorescences with higher than second-order degree of branching. In these cases, spikelets develop on the end of the third-order branches following an acropetal 

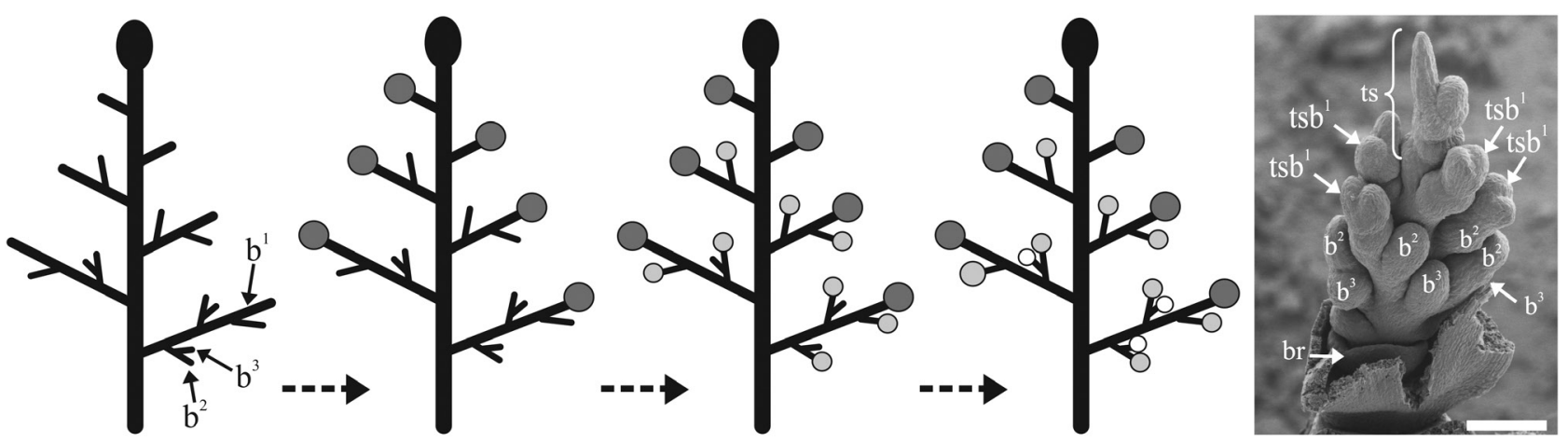

A

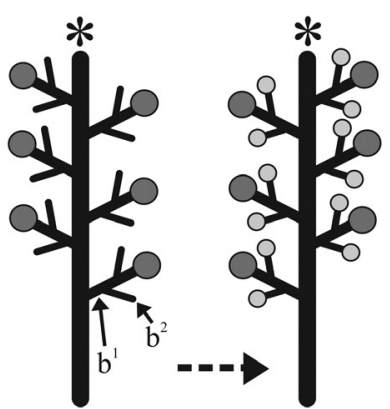

B

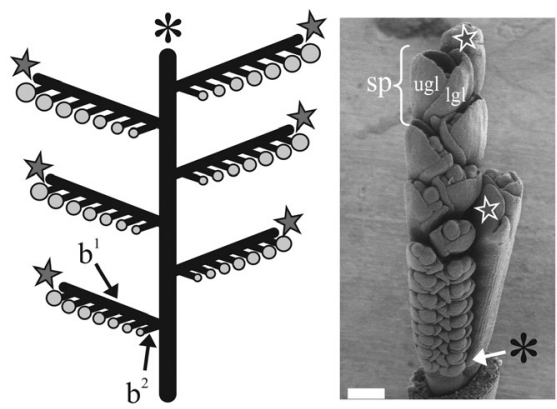

$\mathrm{C}$

Figure 8. Three different developmental sequences of spikelet and floral initiation along the inflorescences. A, Sequence A: the terminal spikelet initiates first, followed by consecutive spikelets and flowers, e.g. Muhlenbergia tenuifolia (scanning electron micrographs). B, Sequence B: the spikelet and flowers at the tip of the first-order branch initiate first due to the absence of terminal spikelet, e.g. Muhlenbergia bryophilus (scanning electron micrographs). C, Sequence C: the distal spikelet and flowers in the first-order branch initiate first, due to the absence of the terminal spikelet at the end of main axis and first-order branches, e.g. Bouteloua barbata (scanning electron micrographs).

sequence of initiation on the second-order branches and in the whole inflorescence (Fig. 8A).

\section{DEVELOPMENT OF THE FLOWERS}

Flower formation within the spikelets begins after glumes have been initiated. The different patterns and directions of initiation of flowers in the inflorescence and on the second- and third-order branches match those of the spikelets (Fig. 8). Tables 4 and 5 outline the most important variations observed during the development of floral organs.

In many-flowered spikelets, flowers initiate in an acropetal direction (Fig. 7A). Mulenbergia asperifolius usually has single-flowered spikelets, although it may occasionally develop two or three flowers. When this happens, the initiation sequence of floral organs follows the previously described pattern (Fig. 9A).

Erioneuron avenaceum (Kunth) Tateoka and all studied species of Bouteloua, Munroa and Muhlenbergia have spikelets with bisexual flowers. Additionally, the studied Distichlis spp. and $M$. mendocina Phil. show unisexual flowers. In particular, Distichlis is a dioecious genus with spikelets having staminate and pistillate flowers in separate individuals. Munroa mendocina is a gynomonoecious species, which develops pistillate flowers (basal flower) and bisexual flowers (distal flower) within the same spikelet.

Development of floral organs in bisexual flowers was found to be similar in all the species studied. After glumes have been developed, the lemma initiates followed by a palea primordium borne in an alternate position, opposite the lemma (Fig. 9B). Both these structures enclose the remaining floral meristem that will give rise to the other floral organs (Fig. 9C). Then, stamen primordia initiate simultaneously. The number of stamen primordia per flower may be: three (two lateral and one abaxial), as in species of Bouteloua and Muhlenbergia (Fig. 9C); two lateral only, as in Munroa (Fig. 9D); or one abaxial only, as in E. avenaceum (Fig. 9E). Subsequently, two lodicules 
Table 4. Differences observed during the flower development of the genus Distichlis, Bouteloua, Muhlenbergia and Munroa

\begin{tabular}{|c|c|c|c|c|}
\hline Species & $\begin{array}{l}\text { Direction of } \\
\text { flower initiation } \\
\text { along the } \mathrm{i}\end{array}$ & $\begin{array}{l}\text { Direction of } \\
\text { flower initiation } \\
\text { on the } b^{1}\end{array}$ & Flowers per spikelet & $\begin{array}{l}\text { Direction of } \\
\text { flower initiation } \\
\text { within spikelet }\end{array}$ \\
\hline Distichlis spicata (staminate) & $?$ & $?$ & Multi-flowered & Acropetal \\
\hline Distichlis spicata (pistillate) & $?$ & $?$ & Multi-flowered & Acropetal \\
\hline Distichlis acerosa (staminate) & - & - & Multi-flowered & Acropetal \\
\hline Distichlis acerosa (pistillate) & - & - & Multi-flowered & Acropetal \\
\hline Distichlis humilis (pistillate) & $?$ & $?$ & Multi-flowered & Acropetal \\
\hline Bouteloua aristidoides & Pattern C & Basipetal & Multi-flowered & Acropetal \\
\hline Bouteloua barbata & Pattern $\mathrm{C}$ & Basipetal & Multi-flowered & Acropetal \\
\hline Bouteloua curtipendula & Pattern C & Basipetal & Multi-flowered & Acropetal \\
\hline Bouteloua megapotamica & Pattern C & Basipetal & Multi-flowered & Acropetal \\
\hline Bouteloua simplex & Pattern C & Basipetal & Multi-flowered & Acropetal \\
\hline Erioneuron avenaceum & $?$ & $?$ & Multi-flowered & Acropetal \\
\hline Muhlenbergia asperifolia & Pattern A & Basipetal & $\begin{array}{l}\text { Uni-flowered } \\
\text { [Two- three flowered] }\end{array}$ & [Acropetal] \\
\hline Muhlenbergia bryophilus & Pattern B & Basipetal & Uni-flowered & - \\
\hline Muhlenbergia peruviana & Pattern A & Basipetal & Uni-flowered & - \\
\hline Muhlenbergia tenuifolia & Pattern A & Basipetal & Uni-flowered & - \\
\hline Munroa argentina & Pattern A & - & Multi-flowered & Acropetal \\
\hline Munroa decumbens & Pattern A & - & Multi-flowered & Acropetal \\
\hline $\begin{array}{l}\text { Munroa mendocina } \\
\text { pistillate flower }\end{array}$ & Pattern A & - & Multi-flowered & Acropetal \\
\hline
\end{tabular}

Abbreviations: $b^{1}$, branch of first order; i, inflorescence; (-) non-applicable; (?) missing data; [] sometimes observed.

initiate forming a whorl outside the stamen primordia and, finally, the gynoecium primordium initiates from the remaining floral meristem (Fig. 9C). The lemma and palea continue growing, enclosing the sexual organs and lodicules. The lemma always shows a more advanced degree of development compared to the palea (Fig. 9C, D). Once all the floral organs are initiated, the gynoecium begins to differentiate with the initiation of carpels, delimiting the meristem that will give origin to one single ovule. At the same time, stamen primordia expand to form the thecae and develop the connective tissue (Fig. 9F). Stamen, lodicule and gynoecium differentiation continues within the lemma and palea. At this stage, styles initiate their development, lodicules gradually take on their final form and thecae continue expanding and lengthening (Fig. 9G). By the time floral development ends, the carpels cover the ovule completely, the styles begin to lengthen and the stigmatic branches initiate on their distal ends. Simultaneously, stamen filaments elongate, lodicules complete their development and glumes, lemmas and paleas continue developing until they reach their final form, size and ornamentation (Fig. 9H, I).

Based on the sequence of floral development described above, some differences have been identified in the initiation and differentiation of floral organs that determine the formation of unisexual flowers. In
D. acerosa, the floral meristem aborts after initiating the three stamen primordia and before initiating the carpels (Fig. 10A-C). In D. spicata (L.) Greene, the gynoecium arrests its development later, after initiating the stigmas on the distal ends of the styles (Fig. 10D-F). In both species, the stamens initiate the formation of the thecae and the connective tissue and continue developing in a normal fashion (Fig. 10B, E). Finally, both species show three developed stamens. In $D$. acerosa, lodicules stop developing before the elongation of filaments and anthers, which means they are not visible in the mature spikelets (Fig. 10C). In D. spicata, lodicules continue their normal development and can be seen at maturity (Fig. 10F).

In $D$. acerosa and D. spicata, two stamen primordia located on the sides of the floral meristem initiate first, followed by the abaxial stamen (Fig. 11A, B, F, G). In D. humilis Phil. and $M$. mendocina, all stamen primordia initiate at the same time (Fig. 11J, N). In $D$. spicata and D. humilis, the two lodicules initiate, forming a whorl outside the stamen primordia (Fig. $11 \mathrm{~K})$. All species initiate carpels, which continue their normal development (Figs 11C, D, G, H, K, L, $\mathrm{O}, \mathrm{P})$. In $D$. acerosa, the stamen primordia remain undifferentiated and arrest their development at the time of style initiation in the gynoecium (Fig. 11D). Meanwhile, in D. spicata and D. humilis, 
Table 5. Differences observed during flower development in Distichlis, Bouteloua, Muhlenbergia and Munroa

\begin{tabular}{|c|c|c|c|c|c|c|c|}
\hline Species & $\begin{array}{l}\text { Sexuality } \\
\text { of flowers }\end{array}$ & $\begin{array}{l}\text { Initiation } \\
\text { of lodicules }\end{array}$ & $\begin{array}{l}\text { Initiation } \\
\text { of stamen } \\
\text { primordia }\end{array}$ & $\begin{array}{l}\text { Stamen } \\
\text { development }\end{array}$ & $\begin{array}{l}\text { Initiation of } \\
\text { gynoecium } \\
\text { primordium }\end{array}$ & $\begin{array}{l}\text { Gynoecium } \\
\text { development }\end{array}$ & $\begin{array}{l}\text { Sterile } \\
\text { flower } \\
\text { development }\end{array}$ \\
\hline $\begin{array}{l}\text { Distichlis spicata } \\
\text { (staminate) }\end{array}$ & Unisexual & Yes & 3 & 3 & Yes & No & No \\
\hline $\begin{array}{l}\text { Distichlis spicata } \\
\text { (pistillate) }\end{array}$ & Unisexual & Yes & 3 & - & Yes & Yes & No \\
\hline $\begin{array}{l}\text { Distichlis acerosa } \\
\text { (staminate) }\end{array}$ & Unisexual & Yes & 3 & 3 & No & No & No \\
\hline $\begin{array}{l}\text { Distichlis acerosa } \\
\text { (pistillate) }\end{array}$ & Unisexual & No & 3 & - & Yes & Yes & No \\
\hline $\begin{array}{l}\text { Distichlis humilis } \\
\text { (pistillate) }\end{array}$ & Unisexual & Yes & 3 & - & Yes & Yes & No \\
\hline $\begin{array}{l}\text { Bouteloua } \\
\text { aristidoides }\end{array}$ & Bisexual & Yes & 3 & 3 & Yes & Yes & Yes \\
\hline Bouteloua barbata & Bisexual & Yes & 3 & 3 & Yes & Yes & Yes \\
\hline $\begin{array}{l}\text { Bouteloua } \\
\text { curtipendula }\end{array}$ & Bisexual & Yes & 3 & 3 & Yes & Yes & Yes \\
\hline $\begin{array}{l}\text { Bouteloua } \\
\text { megapotamica }\end{array}$ & Bisexual & Yes & 3 & 3 & Yes & Yes & Yes \\
\hline Bouteloua simplex & Bisexual & Yes & 3 & 3 & Yes & Yes & Yes \\
\hline $\begin{array}{l}\text { Erioneuron } \\
\text { avenaceum }\end{array}$ & Bisexual & Yes & 1 & 1 & Yes & Yes & No \\
\hline $\begin{array}{l}\text { Muhlenbergia } \\
\text { asperifolia }\end{array}$ & Bisexual & Yes & 3 & 3 & Yes & Yes & No \\
\hline $\begin{array}{l}\text { Muhlenbergia } \\
\text { bryophilus }\end{array}$ & Bisexual & Yes & 3 & 3 & Yes & Yes & No \\
\hline $\begin{array}{l}\text { Muhlenbergia } \\
\text { peruviana }\end{array}$ & Bisexual & Yes & 3 & 3 & Yes & Yes & No \\
\hline $\begin{array}{l}\text { Muhlenbergia } \\
\text { tenuifolia }\end{array}$ & Bisexual & Yes & 3 & 3 & Yes & Yes & No \\
\hline Munroa argentina & Bisexual & Yes & 2 & 2 & Yes & Yes & No \\
\hline Munroa decumbens & sisexual & Yes & 2 & 2 & Yes & Yes & No \\
\hline $\begin{array}{l}\text { Munroa mendocina } \\
\text { (pistillate) }\end{array}$ & Unisexual & No & 2 & - & Yes & Yes & No \\
\hline
\end{tabular}

Abbreviations: (-) non-applicable.

differentiated stamens stop developing after initiating the formation of the thecae and the connective tissue and before the elongation of the filaments (Figs 11I, L). In M. mendocina, the stamens stop developing after the elongation of the filaments (Fig. 11P, Q). Finally, all species show a developed gynoecium and two or three staminodia (Fig. 11E, I, M, Q). In D. spicata and D. humilis, lodicules continue their normal growth and can be seen at maturity (Fig. 11I, M).

Many-flowered spikelets of Bouteloua comprise a proximal bisexual flower and one to several distal sterile flowers that do not develop sexual organs (Fig. 12). In the studied Bouteloua spp., whereas the bisexual flower initiates and develops the floral organs, the apical flowers initiate only the lemma, which differentiates into three awns that vary in length (Fig. 12C, D). In general, Bouteloua spp. develop one single sterile flower (Fig. 12E), except for B. megapotamica (Spreng.) Kuntze, which shows two or three rudimentary flowers (Fig. 12F).

\section{DISCUSSION}

\section{CHANGES IN THE APICAL MERISTEM RELATED TO THE TRANSITION TO FLOWERING}

The transition from vegetative to reproductive state occurs when the apical meristem receives an endogenous signal (e.g. hormonal) or an exogenous stimulus (e.g. light, heat) and acquires the capacity to produce an inflorescence (Colasanti \& Coneva, 2009; Wellmer \& Riechmann, 2010). Morphologically 

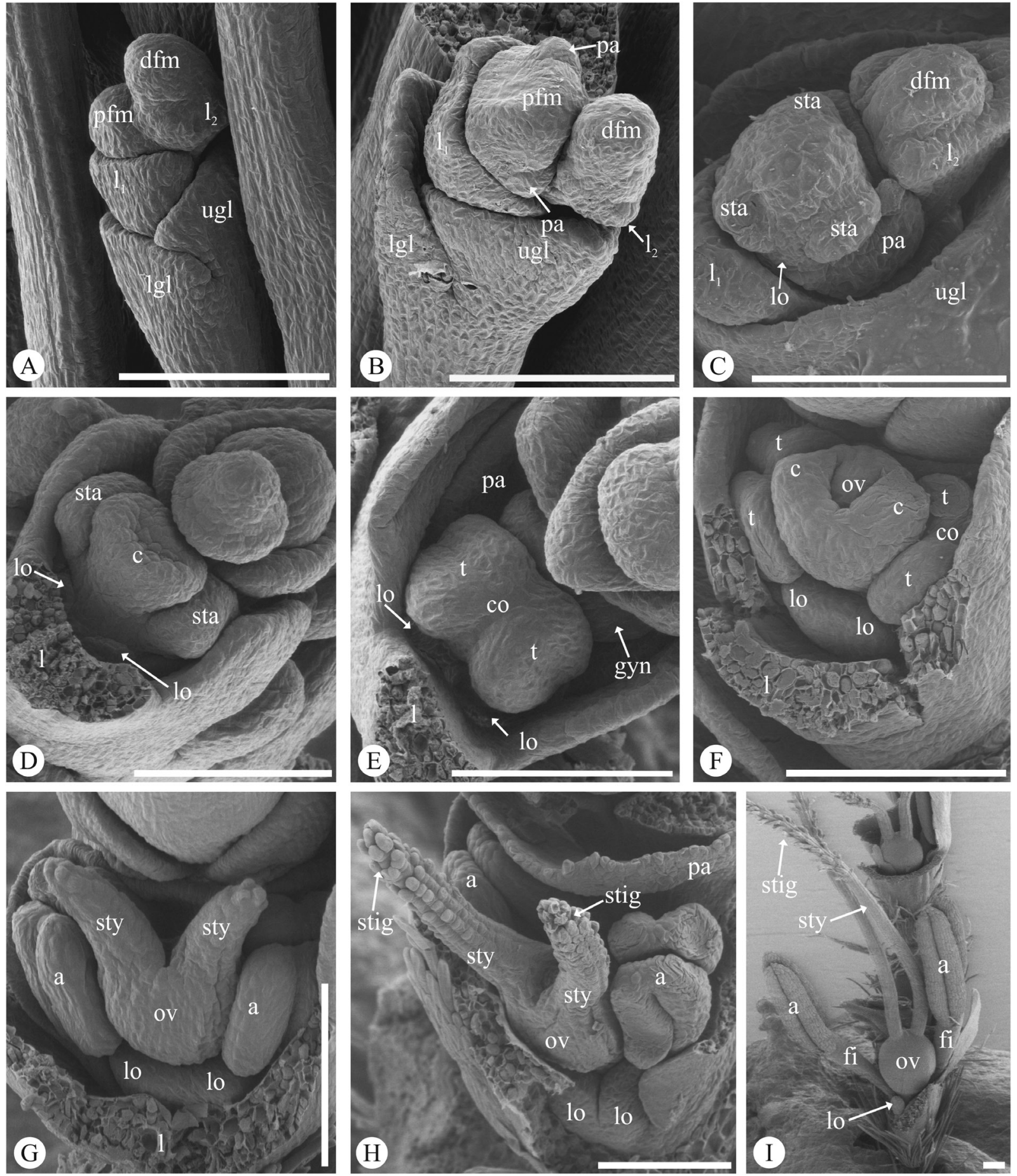

Figure 9. Development of floral organs in bisexual flower (scanning electron micrographs). A-B, Development of spikelet and flowers in Muhlenbergia asperifolius. A, Glume and lemma initiation in the proximal and distal flower, in acropetal direction. B, Palea initiation in the proximal flower. C, Primordium initiation of three stamen and lodicules in Bouteloua barbata. D, Primordium initiation of two lateral stamen and lodicules in Munroa argentina. E, Primordium initiation of abaxial stamen and lodicules in Erioneuron avenaceum. F-I. Flower development of Munroa decumbens. F, Theca and stamen connective tissue initiation. Developing carpels limits the meristem that will originate the unique ovule. G, Stamen and style elongation and lodicule expansion. H, Stigma initiation in the distal portion of styles. I, Gynoecium differentiation, lodicule expansion and stamen filament elongation. 

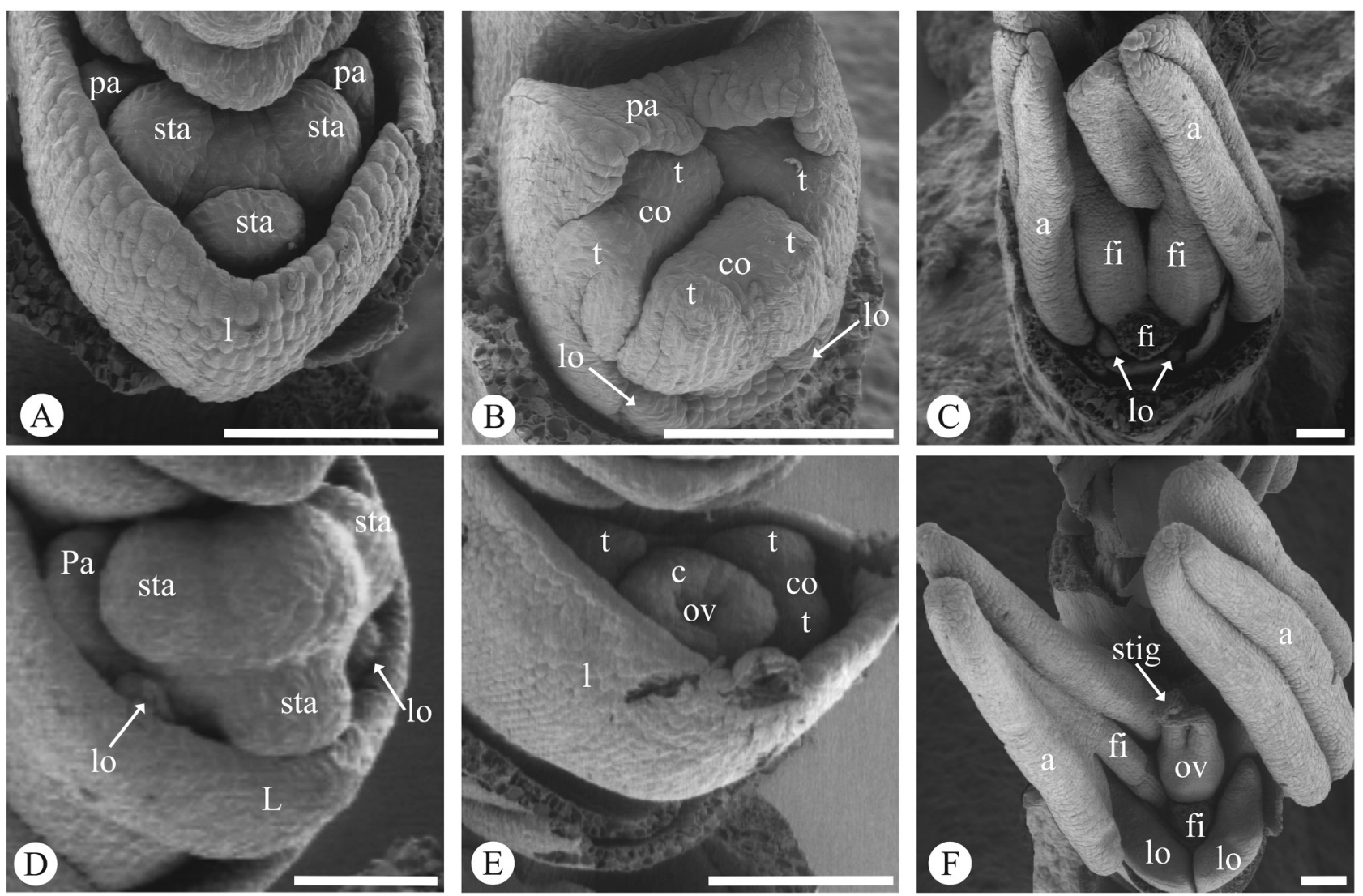

Figure 10. Development of floral organs in staminate flowers (scanning electron micrographs). A-C. Development of the staminate flower of Distichlis acerosa. A, Primordium initiation of stamens, lemma and palea differentiation; no carpel initiation is observed. B, Theca and stamen connective tissue initiation, lodicule initiation and palea expansion over the stamens. C, Anther and stamen filament elongation, lodicules remain reduced, gynoecium is absent. D-F, Development of the staminate flower of Distichlis spicata. D, Primordium initiation of three stamens around the floral meristem, lodicule initiation. E, Theca, stamen connective tissues and carpel differentiation. F, After stigma initiation in the distal portion of styles the gynoecium arrests its development. Stamen filaments, anther and lodicules continue to grow.

speaking, the transition to flowering in the studied species becomes evident when the apical meristem elongates above the latest formed primordium, just as it has been observed in other members of Poaceae (Orr \& Sundberg, 1994; Doust \& Kellogg, 2002; Reinheimer et al., 2005a, 2009; Liu et al., 2007; Zanotti, Pozner \& Morrone, 2010; Kellogg et al., 2013; Hodge \& Kellogg, 2014). Indeed, the vegetative apical meristem is shorter and broader and becomes taller and narrow after transition to flowering (reviewed in Kellogg et al., 2013; Kellogg, 2015).

\section{DEVELOPMENT OF THE BRANCHING SYSTEM OF THE INFLORESCENCE}

The acropetal direction of initiation of the first-order branches seen in the studied species is in line with the most common pattern among grasses (Moncur, 1981; Fraser \& Kokko, 1993; Sundberg \& Orr, 1996; Doust
\& Kellogg, 2002; Ikeda, Sunohara \& Nagato, 2004; Kellogg et al., 2004; Bess et al., 2005; Reinheimer et al., 2005a, 2010; Hodge \& Kellogg, 2014). The first primordium of the first-order branch originates in the axil of the most proximal bract primordium that does not develop completely and is almost unnoticeable when the inflorescence is mature. Indeed, most of the grasses have the ability to suppress bracts development in their inflorescences, except for the ones that form the spikelet. Bract suppression is a common theme in grasses, but why this happens is still an open question. It has been reported that mutants that show welldeveloped bracts have reduced inflorescence branching suggesting that there is a connection between bract growth and meristem determinacy (Chuck et al., 2010; Whipple et al., 2010; Whipple, 2017). Additionally, even when bracts are imperceptible under the microscope, the corresponding cells have started the molecular program that inhibits bract outgrowth (Wang et al., 

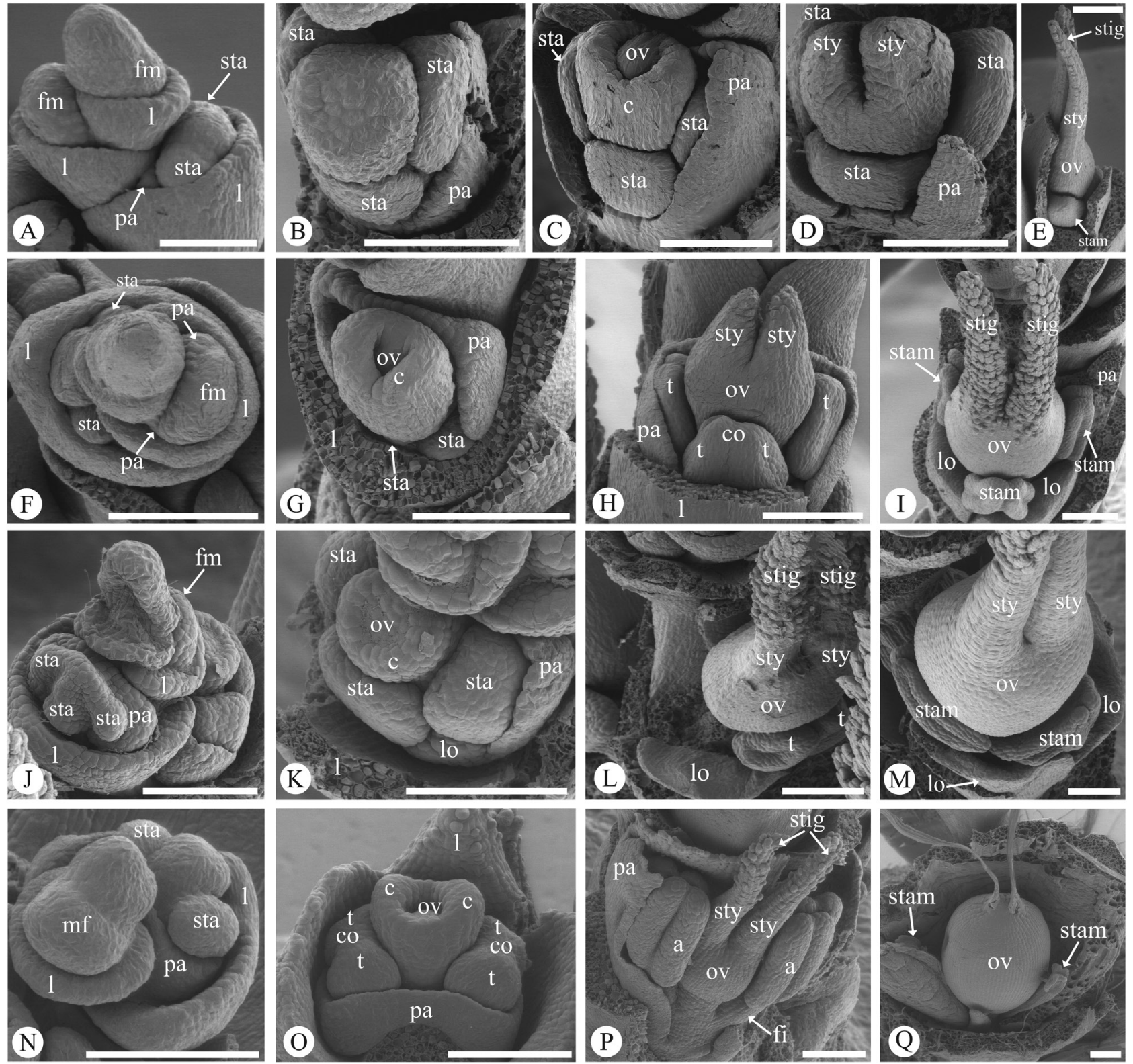

Figure 11. Development of floral organs in pistillate flowers (scanning electron micrographs). A-E, Development of the pistillate flower of Distichlis acerosa. A, Lemma, palea and stamen primordium initiation. B, Stamen development, no lodicule primordium observed. C, Palea expansion and developing carpels delimiting the meristem that will give rise to the only ovule. D, Initiation of two-style primordium; stamen primordium remains undifferentiated. E, Style elongation and stigma initiation in the distal portion of styles. F-I, Development of the pistillate flower of Distichlis spicata. F, Lemma and palea initiation delimiting floral meristem; in the basal flower, initiation of the lateral stamen primordium is observed. G, Developing carpels delimits the meristem that will give rise to the ovule, initiation of the abaxial stamen primordium and palea expansion. H, Theca and stamen connective tissue initiation, style elongation. I, Gynoecium and lodicules continue to growth, but the stamens stop developing before filament elongation, becoming staminoids. J-M, Development of the pistillate flower of Distichlis humilis. J, Initiation of lemma, palea and three stamen primordia. K, Initiation of lodicules and carpels limiting the meristem that will give rise to the only ovule. L, Ovary, style and stigma differentiation, theca and stamen initiation and expansion of lodicules. M, Stamens stop developing before filament elongation, becoming staminoids, gynoecium and lodicules continue to expand. $\mathrm{N}-\mathrm{Q}$, Development of the pistillate flower of Munroa mendocina. N, Initiation of lemma, palea and two stamen primordia. O, Theca and stamen connective tissue initiation, developing carpels limit the meristem that will give rise to the only ovule. P, Style and stamens filament elongation, stigma initiation in the distal portion of styles. Q, Pistillate flower surrounded by two staminoids (altered anthers). 

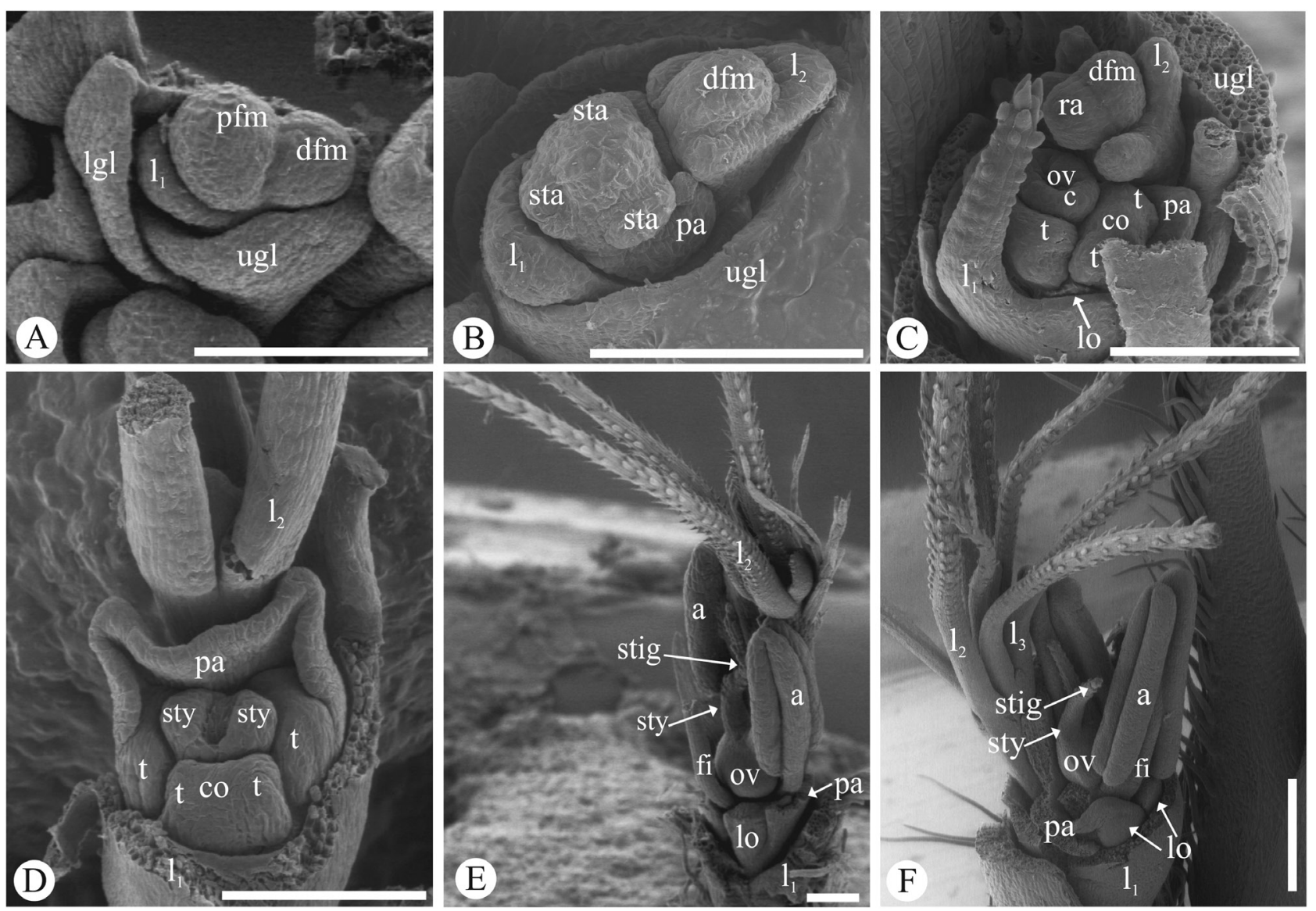

Figure 12. Development of sterile flowers (scanning electron micrographs). A-E, Development of bisexual and sterile flower of Bouteloua barbata. A, Glume differentiation and lemma initiation in the proximal flower and acropetal development of floral meristems. B, Initiation of stamen primordia and palea in the proximal flower; initiation of the three lemma awns in the distal flower. C, Lemma, stamens and carpel differentiation in the proximal flower; retarded development of the distal flower. D, Palea differentiation and styles primordium initiation in the proximal flower; elongation of lemma awns in the sterile distal flower. E, Advanced developmental state of the bisexual proximal flower and sterile distal flower. F, Development of the bisexual proximal flower and the sterile distal flowers of Bouteloua megapotamica.

2009; Chuck et al., 2010; Whipple et al., 2010; Houston et al., 2012). In line with this, bract suppression has been recently thought as novel and localized signaling center that regulates the performance of the adjacent meristem; however, the molecular basis of how the proposed signaling center operates is still unknown (Whipple, 2017).

In Cynodonteae, after the initiation of the first-order branches, the apical meristem of the inflorescence may end with the development of a terminal spikelet, as it has been observed in other grasses [e.g. Avena sativa L., Brachypodium distachyon (L.) P.Beauv., Hyparrhenia hirta (L.) Stapf, Melinis repens (Willd.) Zizka, Phalaris arundinacea L., Sorghum bicolor (L.) Moench and Triticum aestivum L.; Moncur, 1981; Le Roux \& Kellogg, 1999; Reinheimer et al., 2005b, 2009; Kellogg et al., 2013). Alternatively, the apical meristem may arrest its activity before initiating the terminal spikelet. The lack of a terminal spikelet has also been observed in Chloris barbata Sw., Eleusine coracana (L.) Gaertn., Hordeum vulgare L., Oryza sativa L., Zea mays L. and species of Cenchrus L., Eriochloa Kunth and Setaria P.Beauv., among others (Bonnett, 1940; Doust \& Kellogg, 2002; Ikeda et al., 2004; Reinheimer et al., 2005b; 2009; Liu et al., 2007; Kellogg et al., 2013). The fate of the apical meristem of the inflorescence often varies among closely related species, genera and subtribes. This suggests that it may be a relatively labile character in evolutionary time (Kellogg et al., 2013; Kellogg, 2015).

Three different patterns of arrangement of firstorder branches have been identified in the studied species: (1) spiral; (2) strictly distichous and (3) dorsiventral distichous (Endress 2006; also named as 'biased distichous' by Ikeda, Nagasawa \& Nagato, 2005; 'two-ranked non-symmetrical' by Kellogg, 
2015; 'pendulum symmetry' by Charlton, 1997). The arrangement of first-order branches determines the symmetry of the inflorescence, which is a consistent character in each species studied. However, species in each genus may exhibit different types of symmetry, as observed in other grasses (Le Roux \& Kellogg, 1999; Liu et al., 2007; Reinheimer et al., 2009; Kellogg et al., 2013). It has been postulated that the ancestor of grasses may have had a spiral inflorescence and strictly distichous and dorsiventral distichous inflorescences may be derived states (Kellogg et al., 2013). Based on previous phylogenetic reconstructions of Cynodonteae (Soreng et al., 2015; Peterson et al., 2015, 2016), we suggest that the dorsiventral distichous inflorescences appear at least twice independently in Cynodonteae (one in Boutelouinae and one in Muhlenbergiinae) and may be derived from ancestors with distichous or spiral inflorescence.

In grasses, the spiral and dorsiventral distichous inflorescence phyllotaxis requires a change in the phyllotactic pattern of the apical meristem that was producing leaves in strictly distichous manner before transition to flowering. Previous reports on early inflorescence development of non-grass species postulate that the shape and size of the apical meristem after transition to flowering limits the type, disposition and number of organs that the meristem will initiate (Bull-Hereñu \& Claßen-Bockhoff; 2011a, b; ClaßenBockhoff \& Kester Bull-Hereñu, 2013). Nonetheless, it is unclear whether this trend applies for grasses. In addition, it is uncertain if this parameter will be informative alone, without accurate measurements of the size/shape of the lateral organs that the meristem will develop (Jean, 1994; Doust, 2001). Unfortunately, based in our data, we are far to test this hypothesis given that we investigated only a relatively small number of species and we did not measure the apical and lateral meristems accurately.
A combined analysis of the first-order branches of initiation and the three directions of differentiation (initiation of second-order branches) along the inflorescence main axis leads to recognize three paths of development of the first-order branches (Fig. 13A, B): (1) acropetal initiation and differentiation, as observed in some Paniceae (Doust \& Kellogg, 2002; Bess et al., 2005; Reinheimer et al., 2005a, 2009) and Pooideae [in Diarrhena obovata (Gleason) Brandenburg, Kellogg et al., 2013]; (2) acropetal initiation and amphipetal differentiation as reported here for B. curtipendula, with no other records in grasses and (3) acropetal initiation and basipetal differentiation, as observed in some species of Paniceae (Doust \& Kellogg, 2002; Bess et al., 2005; Reinheimer et al., 2009). The presence of such developmental events in disparate lineages suggest that they may have arisen independently more than once during grass evolution. When the mature architecture and the developmental patterns of firstorder branches were analysed together, we found that similarly mature inflorescences from disparate grasses develop following similar developmental patterns of first-order branch initiation and differentiation. Indeed, a panicle of spikelets with terminal spikelet and non-homogenized branching (as shown in Fig. 1A) exhibits an acropetal initiation and differentiation of first-order branches, as shown here and previously in other Pooideae and Paniceae (Doust \& Kellogg, 2002; Bess et al., 2005; Reinheimer et al., 2005a, 2009; Kellogg et al., 2013). In contrast, we observed that in those inflorescences where the terminal spikelet at the end of the main axis does not develop (as shown in Fig. $1 C, D)$, the direction of differentiation of first-order branches may be amphipetal or basipetal along the inflorescence. Recently, it has been demonstrated that a delicate homeostasis among three principal hormones (auxin, cytokinin and gibberellin) controls the acropetal formation of barley inflorescence branching (Youssef et al., 2017). Then, it is possible that a loss of

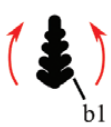

A

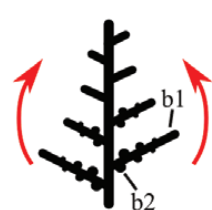

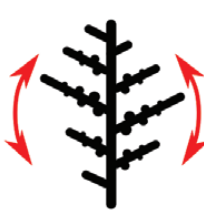

B
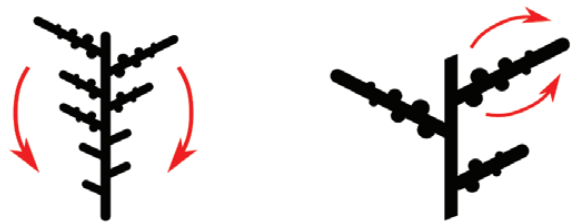

C

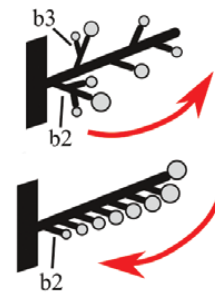

D

Figure 13. Schematic diagram summarizing the main results relating to the direction of initiation and differentiation of inflorescence branching. A, Acropetal initiation of first-order branches. B, Three distinct directions of first-order branch differentiation (from left to right, acropetal, amphipetal, basipetal). C, Acropetal initiation of second-order branches on the first-order branch. D, Two distinct directions of second-order branch differentiation on first-order branches (above, acropetal; bellow, basipetal). 
apical dominance by the premature arrest of the apical meristem generates a hormonal imbalance making the restoration of the acropetal pattern impossible. This hypothesis opens a new developmental dimension controlled by hormone homoeostasis that requires further exploration.

In the studied group, second-order branches initiate along first-order branches in an acropetal direction as in most of grasses studied so far (e.g. Doust \& Kellogg, 2002; Bess et al., 2005; Reinheimer et al., 2005a, 2009; Liu et al., 2007) (Fig. 13C). Nonetheless, in some species of Melinidinae direction of initiation of second-order branches may be amphipetal, e.g. in Urochloa plantaginea (Link) R.D.Webster [=Brachiaria plantaginea (Link) Hitchc.], or basipetal, e.g. in U. panicoides P.Beauv. (Reinheimer et al., 2005a, 2009). Additionally, second-order branches may show an acropetal or basipetal differentiation depending on the species studied (Fig. 13D). Acropetal differentiation was observed here, in inflorescences where their secondorder branches will differentiate into third-order branches. In contrast, basipetal differentiation happens in inflorescences where second-order branches will end with the formation of a spikelet. Based on these findings, we suggest that the direction in which second-order branches differentiate on the first-order branches might be related to the final fate of the meristem of secondorder branches. In other words, if apical meristem of second-order branches is determinate, differentiation is basipetal, whereas it is acropetal when the meristem will continue producing new branches. This observation suggests that the direction of differentiation of secondorder branches on subtending ones may not depend on the presence/absence of the apical dominance as firstorder branches probably do.

\section{ELONGATION OF THE INTERNODES}

Elongation of the internodes of main axis and of firstorder branches may take place in either a proportional or a differential way, generating, in the latter case, occasional whorled branches (close proximity of a set of first-order branches). Generally speaking, in most of the studied species, the elongation of inflorescence internodes and pedicels occurs when flowers have developed. The elongation of the internodes during late stages of inflorescence development has been proved for many grass species (Doust \& Kellogg, 2002; Kellogg et al., 2004; Bess et al., 2005; Reinheimer et al., 2005a, 2009; Malcomber et al., 2006). This time lapse that separates the initiation and differentiation of branch primordia with the elongation of internodes suggests that both developmental events are under independent and distinct genetic controls, as previously postulated (Doust \& Kellogg, 2002). We have observed that the elongation of internodes of first-order branches and pedicel in the inflorescence of $M$. asperifolius takes place before the initiation of floral organs. This observation is the first record for Chloridoideae and for Poaceae in general. Nonetheless, the biological meaning of the premature internodes and pedicels elongation is unknown.

\section{DEVELOPMENT OF THE SPIKELETS}

We observed that glumes develop acropetally in most of the species. Our study proved the absence of glumes in $D$. acerosa, which is consistent with Villamil's descriptions (1969). In contrast, in M. mendocina it was observed that glume primordia initiate but arrest their development at an early stage and, therefore, glumes are not visible in mature spikelets. This observation is largely consistent with the descriptions of mature spikelets by Anton et al. (1978).

Spikelet initiation follows a basipetal direction along the inflorescence and proceeds from the lower-order spikelet to the higher-order spikelets. This trend has been observed in most grasses studied so far (Doust \& Kellogg, 2002; Bess et al., 2005; Reinheimer et al., 2005a; Liu et al., 2007; Reinheimer, 2007). However, it has been observed in some species of Melinidinae that initiation of the terminal spikelets of first-order branches may occur alternatively in an amphipetal direction (Reinheimer, 2007).

When first-order branches were considered, it was observed that in all the studied species, spikelets initiate in a basipetal direction, regardless of whether the terminal spikelet of the first-order branch develops or not. This is the most common pattern among grasses (Le Roux \& Kellogg, 1999; Reinheimer et al., 2005a; Liu et al., 2007; Reinheimer, 2007; Hodge \& Kellogg, 2014). Nevertheless, there have been records of grass spikelets that initiate in an acropetal [Heteropogon contortus (L.) P.Beauv. ex Roem. \& Schult. and Zea mays, Sundberg \& Orr 1990; Le Roux \& Kellogg, 1999] or an amphipetal direction on the first-order branches (species of Cynodon Rich., Dactyloctenium Willd. and Urochloa, Liu et al., 2007; Reinheimer, 2007).

The wide variation in the direction of spikelet initiation and differentiation among grasses and the lack of correlation with presence/absence of apical dominance and direction of initiation of inflorescence branches may suggest that this stage of development is controlled by a mechanism that works independently of the one that controls branching. The testing of such a hypothesis will require more focused sampling across grasses.

\section{DEVELOPMENT OF FLOWERS}

Flower development was analysed considering patterns of initiation and differentiation: (1) along 
the whole inflorescence and primary branches and (2) within the spikelet. Flowers along the inflorescence and on first-order branches follow a basipetal pattern of initiation, just like spikelets. This is the most common direction of flower initiation among grasses (Doust \& Kellogg, 2002; Bess et al., 2005; Reinheimer et al., 2005a; Reinheimer, 2007). However, there have been records of species where flowers initiate in an acropetal direction (e.g. species of Andropogoneae, Sundberg \& Orr 1990; Le Roux \& Kellogg, 1999) or in an amphipetal direction on first-order branches (e.g. species of Paniceae and Cynodonteae, Liu et al., 2007; Reinheimer, 2007). Indeed, in most cases studied so far, direction of flower initiation on first-order branches matches that of the spikelet suggesting a direct link between the initiation of spikelets and flowers. Then, both traits may be regulated by overlapping molecular controls. Still, the biological meaning of this developmental trait is unclear.

Spikelets of the studied group may be single- or many-flowered. In the latter case, direction of flower initiation inside the spikelet is acropetal, as in most of the grasses bearing more than two flowers per spikelet (Kellogg, 2015).

Bisexual flowers initiate the lemma first, followed by the palea, stamens, lodicules and, finally, carpels. This sequence of initiation of floral organs coincides with that observed in other grass genera, including Moorochloa, Eleusine Gaertn., Eriochloa, Melinis, Oryzopsis Michx., Panicum, Pennisetum Rich., Setaria and Urochloa (Clifford, 1987, Reinheimer et al., 2005a, 2010). However, another six patterns of floral organ initiation have been found in Poaceae, which differ from that observed in the species studied here (Clifford, 1987). For example, in Avena L., Bambusa Schreb., Hordeum L., Lolium L., Zea L. and Zizania L., the palea is the first floral organ to be initiated, followed by lodicules, stamens and gynoecium; in the flowers of Triticum L. and Oryza L., the palea initiates first, then stamens, gynoecium and, last, lodicules; in flowers of Bromus L., stamens initiate first, then, lodicules, followed by the palea and gynoecium, or vice versa; in Dactylis L. and Phalaris L., stamens initiate first, next the palea, then lodicules and the gynoecium or vice versa. So far, the functional relevance of such diverse sequences of grass floral organs initiation is unknown.

Stamen primordia initiate between lodicules and the gynoecium. Flowers may develop: two lateral stamen primordia and an abaxial one; only two lateral ones; or an abaxial one. Most grasses have an androecium made up by three stamens (Rudall \& Bateman, 2004; Kellogg, 2015). However, the most likely ancestral state in the grasses is six stamens, a condition that remains in species of subfamilies Anomochlooideae, Oryzoideae, Pharoideae and Puelioideae and in some
Bambusoideae (Zaitchik, Le Roux \& Kellogg, 2000; Sajo et al., 2007; Kellogg, 2015). The reduction of the number of stamens to four has occurred independently in Anomochloa Nakai and in some species of Ehrharta Thunb. (Kellogg, 2015). In some genera, number of stamens has been further reduced to two stamens (e.g. in species of Steirachne Ekman, Peterson et al., 1997) or one stamen (e.g. in species of Bothriochloa Kuntze, Watson \& Dallwitz, 1992).

We observed differences in the direction of initiation of stamen primordia. In most of the studied species, stamen primordia always initiate simultaneously, as in other species of Chloridoideae (Liu et al., 2007). However, in the pistillate flowers of $D$. acerosa and D. spicata, the two stamen primordia located on sides of the floral meristem initiate first with respect to the abaxial stamen. This pattern has also been observed in Eriochloa, Moorochloa eruciformis (Sm.) Veldkamp and some Urochloa spp. (Reinheimer, 2007).

Most grasses have bisexual flowers, although 20-30\% of the species exhibit unisexual flowers, in which only stamens or carpels are functional (Yampolsky \& Yampolsky, 1922). The transition between bisexual and unisexual (staminate or pistillate) flowers has occurred many times during grass diversification; at present, the ancestral state of Poaceae is unknown (Malcomber \& Kellogg, 2006). It is generally believed that unisexual flowers have evolved as a mechanism to promote outcrossing (Charlesworth \& Charlesworth, 1978; Thomson \& Barrett, 1981) and/or allow for sexual resource allocation and specialization (Charlesworth \& Charlesworth, 1978; Brunet \& Charlesworth, 1995). Studies that link changes in the patterns of flower development to sex determination are numerous for Panicoideae (Cheng, Greyson \& Walden, 1983; Sundberg \& Orr, 1990, 1996; Orr \& Sundberg, 1994; Le Roux \& Kellogg 1999; Kellogg et al., 2004; Bess et al., 2005; Reinheimer et al., 2005a, 2010; Hodge \& Kellogg, 2014). However, few studies have been carried out on the Oryzoideae (Zaitchik et al., 2000), Chloridoideae (Liu et al., 2007; Kinney et al., 2008) and Pharoideae (Sajo et al., 2007). Unisexual flowers of Cynondonteae may develop by two distinct paths ('Type I' and 'Type II') that has been previously identified in angiosperms (Mitchell \& Diggle, 2005; Diggle et al., 2011). 'Type I' flowers are bisexual at initiation and then become unisexual with the completion of the development of either the androecium or the gynoecium. In contrast, in 'Type II' flowers sexual differentiation takes place before the initiation of the carpels or stamens. Then 'Type II' flowers are unisexual from the beginning. In the staminate flower of D. spicata, both stamens and gynoecium initiate, but only stamens reach functional maturity, since the growth of the gynoecium is arrested. Then, the pattern of flower development seen in D. spicata coincides with 'Type I' unisexual flowers. This 
type of development has been described for numerous grass species (Cheng et al., 1983; Le Roux \& Kellogg, 1999; Zaitchik et al., 2000; Reinheimer et al., 2005a, 2009; Sajo et al., 2007; Kinney et al., 2008); however, some variation has been observed among grasses in terms of the timing at which the development of the gynoecium is arrested. For instance, in staminate flowers of Panicoideae and Pharoideae studied so far, development of the gynoecium is arrested when the nucellus is visible and carpel walls form a ridge that surrounds it. In these species, the arrest of the development of the gynoecium may entail a process of cell vacuolization and/or cell death, or it may just occur with no evidence of cell breakdown (Cheng et al., 1983; Le Roux \& Kellogg, 1999; Reinheimer et al., 2005a; Sajo et al., 2007). In contrast, the development of the staminate flower in Bouteloua dimorpha Columbus (Chloridoideae) is histologically similar to that of species of Panicoideae and Pharoideae, but the abortion of the gynoecium takes place when the styles initiate (Kinney et al., 2008). Meanwhile, in the staminate flower of Zizania aquatica L. (Oryzoideae), the development of the gynoecium is arrested at a more advanced stage, when the stigmas have initiated, with no evidence of cell vacuolization or cell death (Zaitchik et al., 2000). Based on our records, the moment when gynoecium arrests its development in D. spicata may be similar to that observed in $Z$. aquatica. In these species, the retention of the sterile reproductive structures might be due to intrinsic factors, such as underlying genetic correlations between both sexes (Diggle et al., 2011).

In staminate flower of $D$. acerosa, the floral meristem aborts after initiating the three stamen primordia and before initiating carpels. Therefore, flowers appear to be unisexual from the beginning. This pattern of development coincides with 'Type II' development of unisexual flowers, which means that sexual differentiation in flowers takes place before the initiation of the carpels and stamens (Mitchell \& Diggle, 2005; Diggle et al., 2011). 'Type II' development observed in $D$. acerosa is the first record for grasses. In other Poales and monocots, 'Type I' development of unisexual flowers may prevail (Mitchell \& Diggle, 2005), but there has been records of 'Type II' flowers in Ischyrolepis Steud. (Restionaceae; Mitchell \& Diggle, 2005). 'Type I' has been documented for eudicots including Mercurialis annua L. (Euphorbiaceae, Durand \& Durand, 1991), Spinacia oleracea L. (Amaranthaceae; Sherry, Eckard \& Lord, 1993) and Thalictrum dioicum L. (Ranunculaceae, Di Stilio, Kramer \& Baum, 2005). Flowers of dioecious species of Austrobaileyales, an early-diverging angiosperm group, has been reported as 'Type II' (Mitchell \& Diggle, 2005). The initiation of organs of only one sex in flowers might be related to resource optimization. This means that resources are exclusively allocated to the production of male gametes (Diggle et al., 2011).

The development patterns of staminate flowers of $D$. acerosa and D. spicata described here are the first record for Chloridoideae. In any case, findings obtained in terms of development should be complemented with anatomical studies focused on determining the histological processes involved in the developmental arrest of the gynoecium in $D$. acerosa and D. spicata. This might help identify whether mechanisms involved are divergent to those found in Panicoideae, Pharoideae, Chloridoideae and Oryzoideae.

Pistillate flowers exhibit a 'Type I' pattern of development, in which the organs of both sexes initiate, but only the gynoecium develops completely and the stamens are reduced to staminodia. The timing when the stamens arrest their development varies among grasses. For instance, in $D$. acerosa, the stamens arrest their development before the anthers differentiate and at the same time the styles initiate. Stamens of pistillate flowers of Zea mays, Bouteloua dimorpha and Heteropogon contortus arrest their development after anther differentiation (Cheng et al., 1983; Kinney et al., 2008). In Z. mays, the stamens stop developing because of cell vacuolization and loss of cytoplasmic organelles in the anther lobes (Cheng et al., 1983). Conversely, in stamens of $B$. dimorpha and $H$. contortus, there is no evidence of loss of cellular content or breakdown of nuclei (Le Roux \& Kellogg, 1999; Kinney et al., 2008). In pistillate flowers of $D$. humilis and $D$. spicata, stamens arrest their development after the formation of thecae and connective tissue and before the elongation of filaments. Moreover, in $M$. mendocina, stamens arrest their development after the elongation of the filaments. Developmental data should be complemented with anatomical studies to help determine the underlying mechanisms that may be involved in the arrest of stamens in pistillate flowers.

On the other hand, pistillate flowers of D. acerosa and M. mendocina lack lodicules. It is generally thought that lodicules in grasses play the role of promoting flower opening, which allows stamens to emerge (Soreng \& Davis, 1998). Therefore, large lodicules in staminate flowers might promote pollen dispersal, whereas tiny lodicules in pistillate flowers might have no specific function. This theory might account for the absence of lodicules in flowers of $D$. acerosa, M. mendocina, Pharus P. Browne and Anomochloa and reduced size of lodicules in the pistillate flowers of B. dimorpha (Rudall et al., 2005; Kinney et al., 2008). Nonetheless, this explanation would not be valid for D. spicata and $D$. humilis, since their mature pistillate flowers have large, fleshy lodicules. Based on the differences observed in the development patterns 
that determine flower sexuality, it can be suggested that the mechanisms involved in the production of a staminate unisexual flower and a pistillate unisexual flower should be under different genetic controls as previously postulated (Malcomber et al., 2006).

\section{HigHLIGHTS OF THE DEVELOPMENT OF REPRODUCTIVE BRANCHES AND FLORAL ORGANS IN CYNODONTEAE AND OTHER GRASSES}

Comparative studies on development have been valuable for the analysis of reproductive structures taking into consideration changes that occur along the ontogeny of the inflorescence, the spikelet and the flower. Based on our findings and, consistently with previous studies (Reinheimer et al., 2005a, 2009, 2010; Sajo et al., 2007, 2012; Liu et al., 2007; Kinney et al., 2008), it may be concluded that the inflorescence of disparate grasses with similar structural plan develops following the same model. This becomes evident when the direction of initiation and differentiation of branches is included in the morphological analysis. In line with this, we found four important aspects of grass inflorescence development: (1) direction of differentiation of second order branches on subtending ones may not depend on the presence/absence of the apical dominance as the first-order branches probably do; (2) branching development and internode elongation events may be under independent and distinct genetic controls as previously postulated (Doust \& Kellogg, 2002); (3) direction of spikelet initiation and differentiation may be regulated by a mechanism that works independently of the one that controls branching and and (4) spikelet and flower initiation on primary branches may be regulated by overlapping molecular controls.

Apart from the time dimension, studies on development add a micromorphological aspect, by incorporating data on the structure of organs at different stages of development. The latter has been particularly important in order to identify sterile axes and floral organs that are considered absent in mature state. Studies on the morphogenesis of reproductive systems of grasses reveal a complex morphological dimension, which increases differences among species.

To date, data on the development of branches and floral organs of grasses have been fragmentary and focused on some groups. However, after a comparison of the descriptions on development presented in our work with current knowledge on other grasses, common patterns in grasses may be identified, such as: (1) the elongation of the apical meristem above the latestformed leaf primordium marks the transition of the apical meristem from vegetative to reproductive; (2) the acropetal direction of initiation of first-order branches prevails; (3) the direction of differentiation of the secondorder branches on the first-order branches correlates with the final fate of the apical meristem of the secondorder branches; (4) the elongation of the internodes of the inflorescence branches occurs when flowers have differentiated and (5) the direction of initiation of spikelets and flowers along the inflorescence is always basipetal on the axis that holds them.

Additionally, this work reports developmental patterns that are unique to some species of Cynodonteae and represent first reports for grasses, e.g. (1) the amphipetal initiation of second-order branches along the inflorescence observed in the $B$. curtipendula species, (2) the elongation of the internodes of the inflorescence branches before floral development, as observed in $M$. asperifolius and (3) 'Type II' unisexual flowers of $D$. acerosa.

In conclusion, the current work presents a comparative inflorescence development in Cynodonteae analysed in the context of what we already know from other grasses. The approach used here provides a link between definitive structures and the underlying genetics. In this sense, our results allow us to postulate new hypothesis on grass inflorescence development and evolution. Indeed, by observing and comparing micrographs that document the beginning of inflorescence development in many grasses, we postulate that a delicate balance of phytohormones may command the early development of grass inflorescence branching system by controlling the direction of differentiation of first-order branches. We also think that at some stages of development (more likely those that are under overlapping control), events that occur earlier may generate pleiotropic effects on developmental traits that occur after. It would be of interest to test these hypotheses using a species-level phylogenetic tree as a backbone to further explore whether these aspects are also true on a macroevolutionary scale.

\section{ACKNOWLEDGEMENTS}

The authors would like to thank Dr Juan Carlos Tivano, Dr Juan Manuel Acosta, Dra. Ana María Gonzalez, Dr Héctor Sato and Dr Pablo Ortega Baes for accompanying the authors on numerous field expeditions. We would also like to thank Bioing. Pablo Risso for his assistance with SEM photography. We are also grateful to anonymous reviewers for critically reading the manuscript. This research was supported by PICT-2011-0590 and PICT2015-0681 (to A. V.); PICT-2013-0757 (to R. R.) and UNLCAID + D 2011 (to R.R).

\section{REFERENCES}

Anton AMH, Anton ATAM, Hunziker AT. 1978. El género Munroa-Poaceae-: sinopsis morfológica y taxonómica. Boletín de la Academia Nacional de Ciencias Córdoba 52: 3-4. 
Anton AM, Connor HE, Astegiano ME. 1998. Taxonomy and floral biology of Scleropogon (Eragrostideae: Gramineae). Plant Species Biology 13: 35-50.

Bess EC, Doust AN, Kellogg EA. 2005. A naked grass in the "bristle clade": a phylogenetic and developmental study of Panicum section Bulbosa (Paniceae: Poaceae). International Journal of Plant Sciences 166: 371-381.

Bonnett OT. 1940. Development of the staminate and pistillate inflorescences of sweet corn. Journal of Agricultural Research 60: 25-37.

Brunet J, Charlesworth D. 1995. Floral sex allocation in sequentially blooming plants. Evolution 49: 70-79.

Bull-Hereñu K, Claßen-Bockhoff R. 2011a. Open and closed inflorecences: more than simple opposites. Journal of Experimental Botany 62: 79-88.

Bull-Hereñu K, Claßen-Bockhoff R. 2011b. Ontogenetic course and spatial constraints in the appearance and disappearance of the terminal flower in inflorescences. International Journal of Plant Sciences 172: 471-498.

Charlesworth B, Charlesworth D. 1978. A model for the evolution of dioecy and gynodioecy. The American Naturalist 112: 975-997.

Charlton WA. 1997. Pendulum symmetry. In: Barabé D, Jean RV, eds. Symmetry in plants. Singapore: World Scientific, 61-87.

Cheng PC, Greyson RI, Walden DB. 1983. Organ initiation and the development of unisexual flowers in the tassel and ear of Zea mays. American Journal of Botany 70: 450-462.

Chuck G, Whipple C, Jackson D, Hake S. 2010. The maize SBP-box transcription factor encoded by tasselsheath4 regulates bract development and the establishment of meristem boundaries. Development 137: 1243-1250.

Claßen-Bockhoff R, Bull-Hereñu K. 2013. Towards an ontogenetic understanding of inflorescence diversity. Annals of Botany 112: 1523-1542.

Clayton W, Renvoize SA. 1986. Genera graminum. Grasses of the World. Kew Bulletin Additional Series 13: 1-389.

Clifford HT. 1987. Spikelet and floral morphology. In: Soderstrom TR, Hilu KW, Campbell CS, Barkworth ME eds. Grass systematics and evolution. Washington: Smithsonian Institution Press, 21-30.

Colasanti J, Coneva V. 2009. Mechanisms of floral induction in grasses: something borrowed, something new. Plant Physiology 149: 56-62.

Diggle PK, Di Stilio VS, Gschwend AR, Golenberg EM, Moore RC, Russell JR, Sinclair JP. 2011. Multiple developmental processes underlie sex differentiation in angiosperms. Trends in Genetics 27: 368-376.

Di Stilio VS, Kramer EM, Baum DA. 2005. Floral MADS box genes and homeotic gender dimorphism in Thalictrum dioicum (Ranunculaceae) - a new model for the study of dioecy. The Plant Journal 41: 755-766.

Doust AN. 2001. The developmental basis of floral variation in Drimys winteri (Winteraceae). International Journal of Plant Science 162: 697-717.

Doust AN, Kellogg EA. 2002. Inflorescence diversification in the panicoid "bristle grass" clade (Paniceae, Poaceae): evidence from molecular phylogenies and developmental morphology. American Journal of Botany 89: 1203-1222.
Durand B, Durand R. 1991. Sex determination and reproductive organ differentiation in Mercurialis. Plant Science 80: 49-65.

Endress PK. 2006. Angiosperm floral evolution: morphological developmental framework. Advances in Botanical Research 44: $1-61$.

Frank L. 1998. Análisis del sistema de ramificación del complejo Brachiaria-Urochloa (Poaceae-Paniceae). Bachelor's degree thesis, Universidad de Buenos Aires, Buenos Aires, Argentina.

Fraser J, Kokko EG. 1993. Panicle, spikelet, and floret development in orchardgrass (Dactylis glomerata). Canadian Journal of Botany 71: 523-532.

Herrera Arrieta Y, Peterson PM, De la Cerda Lemus M. 2004. Revisión de Bouteloua Lag. Durango: Comisión Nacional para el Conocimiento y Uso de la Biodiversidad e Instituto Politécnico Nacional.

Hodge JG, Kellogg EA. 2014. Patterns of inflorescence development of three prairie grasses (Andropogoneae, Poaceae). International Journal of Plant Sciences 175: 963-974.

Houston K, Druka A, Bonar N, Macaulay M, Lundqvist U, Franckowiak J, Morgante $M$, Stein N, Waugh R. 2012. Analysis of the barley bract suppression gene Trd1. Theoretical and Applied Genetics 125: 33-45.

Hunziker AT, Anton AM. 1979. A synoptical revision of Blepharidachne (Poaceae). Brittonia 31: 446-453.

Ikeda K, Nagasawa N, Nagato Y. 2005. ABERRANT PANICLE ORGANIZATION 1 temporally regulates meristem identity in rice. Developmental Biology 282: 349-360.

Ikeda K, Sunohara H, Nagato Y. 2004. Developmental course of inflorescence and spikelet in rice. Breeding Science 54: $147-156$.

Jean RV. 1994. Phyllotaxis: a systematic study in plant morphogenesis. Cambridge: Cambridge University Press.

Kellogg EA. 2007. Floral displays: genetic control of grass inflorescences. Current Opinion in Plant Biology 10: 26-31.

Kellogg EA. 2015. Flowering plants. Monocots: Poaceae. In: Kubitzki K, ed. The families and genera of vascular plants. Heidelberg: Springer.

Kellogg EA, Camara PE, Rudall PJ, Ladd P, Malcomber ST, Whipple CJ, Doust AN. 2013. Early inflorescence development in the grasses (Poaceae). Frontiers in Plant Science 4: 250.

Kellogg EA, Hiser KM, Doust AN. 2004. Taxonomy, phylogeny and inflorescence development of the genus Ixophorus (Panicoideae: Poaceae). International Journal of Plant Sciences 165: 1089-1105.

Kinney MS, Columbus JT, Friar EA. 2008. Unisexual flower, spikelet, and inflorescence development in monoecious/ dioecious Bouteloua dimorpha (Poaceae, Chloridoideae). American Journal of Botany 95: 123-132.

Le Roux LG, Kellogg EA. 1999. Floral development and the formation of unisexual spikelets in the Andropogoneae (Poaceae). American Journal of Botany 86: 354-366.

Liu Q, Peterson PM, Columbus JT, Zhao N, Hao G, Zhang D. 2007. Inflorescence diversification in the "finger 
millet clade" (Chloridoideae, Poaceae): a comparison of molecular phylogeny and developmental morphology. American Journal of Botany 94: 1230-1247.

Malcomber ST, Kellogg EA. 2006. Evolution of unisexual flowers in grasses (Poaceae) and the putative sex determination gene, TASSELSEED2 (TS2). New Phytologist 170: 885-899.

Malcomber ST, Preston JC, Reinheimer R, Kossuth J, Kellogg EA. 2006. Grass inflorescence diversity. Advances in Botanical Research 44: 425-481.

Mitchell CH, Diggle PK. 2005. The evolution of unisexual flowers: morphological and functional convergence results from diverse developmental transitions. American Journal of Botany 92: 1068-1076.

Moncur MW. 1981. Floral intiation in field crops. Melbourne: CSIRO.

Negritto MA, Duran ML, Scrivanti LR, Anton AM. 2003. Eragrostideae subtribu Eleusininae. Flora Fanerogámica Argentina 86: 13-68.

Nicora EG, Rúgolo de Agrasar ZE. 1987. Los géneros de gramíneas de América Austral. Buenos Aires: Hemisferio Sur.

Orr AR, Mullen K, Klaahsen D, Sundberg MD. 2002. Inflorescence development in a high-altitude annual Mexican teosinte (Poaceae). American Journal of Botany 89: 1730-1740.

Orr AR, Sundberg MD. 1994. Inflorescence development in a perennial teosinte: Zea perennis (Poaceae). American Journal of Botany 81: 598-608.

Peterson PM, Romaschenko K, Herrera Arrieta Y. 2015. Phylogeny and subgeneric classification of Bouteloua with a new species, $B$. herrera arrietae (Poaceae: Chloridoideae: Cynodonteae: Boutelouinae). Journal of Systematics and Evolution 53: 351-366.

Peterson PM, Romaschenko K, Herrera Arrieta Y. 2016. A molecular phylogeny and classification of the Cynodonteae (Poaceae: Chloridoideae) with four new genera: Orthacanthus, Triplasiella, Tripogonella, and Zaqiqah; three new subtribes: Dactylocteniinae, Orininae, and Zaqiqahinae; and a subgeneric classification of Distichlis. Taxon 65: 1263-1287.

Peterson PM, Valdés-Reyna J, Herrera Arrieta YH. 2007. Muhlenbergiinae (Poaceae: Chloridoideae: Cynodonteae): from northeastern Mexico. Journal of the Botanical Research Institute of Texas 1: 933-1000.

Peterson PM, Webster RD, Valdés-Reyna J. 1997. Genera of New World Eragrostideae (Poaceae: Chloridoideae). Smithsonian Contributions of Botany 87: 1-50.

Pilatti V. 2016. Diversidad y evolución de las inflorescencias en las subtribus más derivadas de Cynodonteae (ChloridoideaePoaceae). Tesis doctoral, Universidad Nacional del Litoral. Facultad de Bioquímica y Ciencias Biológicas, Santa Fe, Argentina.

Pilatti V, Muchut SE, Uberti-Manassero N, Vegetti AC, Reinheimer R. 2017. Diversity, systematics, and evolution of Cynodonteae inflorescences (Chloridoideae - Poaceae). Systematics and Biodiversity 16: 245-259.
Pilatti V, Vegetti A. 2014. Diversity of inflorescences in the Boutelouinae subtribe (Poaceae: Chloridoideae: Cynodonteae). Flora 209: 426-434.

Reinheimer R. 2007. Desarrollo y estructura de la inflorescencia de Brachiaria y Urochloa (Poaceae: Panicoideae: Paniceae) y sus implicancias sistemáticas. Tesis doctoral, Universidad Nacional del Litoral. Facultad de Bioquímica y Ciencias Biológicas, Santa Fe, Argentina.

Reinheimer R, Astegiano ME, Vegetti AC. 2005b. Typology of the inflorescence in species of Sporobolus (SporobolinaeEragrostideae-Poaceae). Kurtziana 31: 7-19.

Reinheimer R, Pozner R, Vegetti AC. 2005a. Inflorescence, spikelet, and floral development in Panicummaximum and Urochloa plantaginea (Poaceae). American Journal of Botany 92: 565-575.

Reinheimer R, Zuloaga FO, Vegetti AC, Pozner R. 2009. Diversification of inflorescence development in the PCK clade (Poaceae: Panicoideae: Paniceae). American Journal of Botany 96: 549-564.

Reinheimer R, Zuloaga FO, Vegetti AC, Pozner R. 2010. Changes in floret development patterns that may correlate with sex determination in the PCK clade (Poaceae). International Journal of Plant Sciences 171: 24-33.

Rúa GH, Weberling F. 1998. Growth form and inflorescence structure of Paspalum L. (Poaceae: Paniceae): a comparative morphological approach. Beiträge zur Biologie der Pflanzen 69: $363-431$.

Rudall PJ, Bateman RM. 2004. Evolution of zygomorphy in monocot flowers: iterative patterns and developmental constraints. New Phytologist 162: 25-44.

Rudall PJ, Stuppy W, Cunniff J, Kellogg EA, Briggs BG. 2005. Evolution of reproductive structures in grasses (Poaceae) inferred by sister-group comparison with their putative closest living relatives, Ecdeiocoleaceae. American Journal of Botany 92: 1432-1443.

Sajo MG, Longhi-Wagner H, Rudall PJ. 2007. Floral development and embryology in the early-divergent grass Pharus. International Journal of Plant Sciences 168: 181-191.

Sajo MG, Pabón-Mora N, Jardim J, Stevenson DW, Rudall PJ. 2012. Homologies of the flower and inflorescence in the early-divergent grass Anomochloa (Poaceae). American Journal of Botany 99: 614-628.

Sherry RA, Eckard KJ, Lord EM. 1993. Flower development in dioecious Spinacia oleracea (Chenopodiaceae). American Journal of Botany 80: 283-291.

Soreng RJ, Davis JI. 1998. Phylogenetics and character evolution in the grass family (Poaceae): simultaneous analysis of morphological and chloroplast DNA restriction site character sets. The Botanical Review 64: 1-85.

Soreng RJ, Peterson PM, Romaschenko K, Davidse G, Zuloaga FO, Judziewicz EJ, Filgueiras TS, Davis JI, Morrone O. 2015. A worldwide phylogenetic classification of the Poaceae (Gramineae). Journal of Systematics and Evolution 53: 117-137.

Stür WW. 1986. Reproductive development of the apex of Brachiaria decumbens Stapf. Annals of Botany 58: 569-575. 
Sundberg MD, Orr AR. 1990. Inflorescence development in two annual teosintes: Zea mays subsp. mexicana and Z. mays subsp. parviglumis. American Journal of Botany 77: 141-152.

Sundberg MD, Orr AR. 1996. Early infl orescence and floral development in Zea mays land race Chapalote (Poaceae). American Journal of Botany 83: 1255-1265.

Thomson JD, Barrett SC. 1981. Selection for outcrossing, sexual selection, and the evolution of dioecy in plants. The American Naturalist 118: 443-449.

Villamil CB. 1969. El género Monanthochloë (Gramineae). Estudios morfologicos y taxonomicos con especial referencia a la species Argentina. Kurtziana 5: 369-391.

Wang L, Yin H, Qian Q, Yang J, Huang C, Hu X, Luo D. 2009. NECK LEAF 1, a GATA type transcription factor, modulates organogenesis by regulating the expression of multiple regulatory genes during reproductive development in rice. Cell Research 19: 598-611.

Watson L, Dallwitz MJ. 1992. The grass genera of the World. Wallingford: C.A.B. International.

Wellmer F, Riechmann JL. 2010. Gene networks controlling the initiation of flower development. Trends in Genetics 26: 519-527.
Whipple CJ. 2017. Grass inflorescence architecture and evolution: the origin of novel signaling centers. The New Phytologist 216: 367-372.

Whipple CJ, Hall DH, DeBlasio S, Taguchi-Shiobara F, Schmidt RJ, Jackson DP. 2010. A conserved mechanism of bract suppression in the grass family. The Plant Cell 22: $565-578$.

Yampolsky C, Yampolsky H. 1922. Distribution of sex forms in the phanerogamic flora. Bibliotheca Genetica 3: 1-63.

Youssef HM, Eggert K, Koppolu R, Alqudah AM, Poursarebani N, Fazeli A, Sakuma S, Tagiri A, Rutten T, Govind G, Lundqvist U, Graner A, Komatsuda T, Sreenivasulu N, Schnurbusch T. 2017. VRS2 regulates hormone-mediated inflorescence patterning in barley. Nature Genetics 49: 157-161.

Zaitchik BF, LeRoux LG, Kellogg EA. 2000. Development of male flowers in Zizania aquatica (North American wildrice; Gramineae). International Journal of Plant Sciences 161: 345-351.

Zanotti CA, Pozner R, Morrone O. 2010. Understanding spikelet orientation in Paniceae (Poaceae). American Journal of Botany 97: 717-729. 